\title{
Antimicrobial, Anti-Inflammatory and Antioxidant Activities of Polyoxygenated Chalcones
}

\author{
Yesseny A. Vásquez-Martínez, ${ }^{a}$ Mauricio E. Osorio, ${ }^{\circledR * b}{ }^{*}$ Diego A. San Martín, ${ }^{b}$ \\ Marcela A. Carvajal, ${ }^{c}$ Alejandra P. Vergara ${ }^{c}$ Elizabeth Sanchez, ${ }^{c}$ Marcela Raimondi, ${ }^{d}$ \\ Susana A. Zacchino, ${ }^{d}$ Carolina Mascayano, ${ }^{e}$ Claudia Torrent, ${ }^{e}$ Francisco Cabezas, ${ }^{e}$ \\ Sophia Mejias, ${ }^{f}$ Margarita Montoya ${ }^{f}$ and Marcelo Cortez-San Martin ${ }^{f}$
} aPrograma Centro de Investigaciones Biomédicas Aplicadas, Facultad de Ciencias Médicas,
Universidad de Santiago de Chile, 9170022 Santiago, Chile

${ }^{b}$ Laboratorio de Productos Naturales, Departamento de Química, Universidad Técnica Federico Santa María, 2390123 Valparaíso, Chile

${ }^{c}$ Centro de Biotecnología CB-DAL, Universidad Técnica Federico Santa María, 2390136 Valparaíso, Chile

${ }^{d}$ Farmacognosia, Facultad de Ciencias Bioquímicas y Farmacéuticas, Universidad Nacional de Rosario, Suipacha 531, 2000 Rosario, Argentina

eDepartamento de Ciencias del Ambiente, Facultad de Química y Biología, Universidad de Santiago de Chile, 9170022 Santiago, Chile

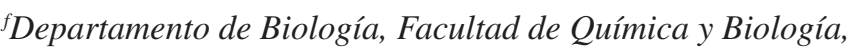
Universidad de Santiago de Chile, 9170022 Santiago, Chile

\begin{abstract}
It was synthesized nine polyoxygenated chalcones with a potential and safe use as antioxidant, antimicrobial and anti-inflammatory therapies. Chalcones obtained by Claisen-Schmidt condensation were studied as antioxidant, inhibitors of human 5-lipoxygenase, antifungal, antibacterial and antibiotic resistance modifiers. Two chalcones with catecholic moieties were able to strongly decrease the minimum inhibitory concentration (MIC) of methicillin against methicillin-resistant Staphylococcus aureus, increase the antiradical activity and significantly inhibit the human 5-lipoxygenase. Only one of these chalcones was active synergistically with methicillin. Chalcones with methoxyl substituents at different positions displayed the best activities against Cryptococcus neoformans. Only one chalcone showed good activity against the plant pathogenic bacteria Pseudomonas syringae whose half maximal inhibitory concentration $\left(\mathrm{IC}_{50}\right)$ value $\left(2.5 \mu \mathrm{g} \mathrm{mL} \mathrm{g}^{-1}\right)$ was similar to that observed with the antibiotic streptomycin $\left(2.9 \mu \mathrm{g} \mathrm{mL} \mathrm{m}^{-1}\right)$. These simple chalcones have safe potential uses in antioxidant, antimicrobial and anti-inflammatory therapies.
\end{abstract}

Keywords: antioxidant activity, polyoxygenated chalcones, human 5-lipoxygenase inhibitors, antibacterial, antifungal

\section{Introduction}

Chalcones (1,3-diphenyl-prop-2-en-1-ones) essentially differ from other flavonoids by its open C-ring, thus possessing a linear chain of three carbon atoms binding A with B ring (Figure 1). ${ }^{1}$ Chalcones have been used as intermediates for the preparation of compounds with therapeutic value. A number of synthetic routes have been reported for the synthesis of chalcones, the Claisen-Schmidt

*e-mail: mauricio.osorio@usm.cl,osomauricio@gmail.com condensation under homogeneous conditions in the presence of acid or base being the most used. Traditionally, strong alkaline media- ${ }^{2-8}$ and the use of several Lewis acids ${ }^{9-15}$ have been employed for their synthesis. Some improved strategies include solvent-free conditions, ${ }^{16}$ microwave $^{17}$ and ultrasound irradiation ${ }^{18}$ and the grinding technique. ${ }^{19}$ The synthesis of chalcones in acid condition using $\mathrm{SOCl}_{2}$ in ethanol to generate $\mathrm{HCl}$ in situ have been used to prepare chalcones with one free hydroxyl group,$^{20}$ however, the synthesis of chalcones with additional oxygenated groups have not been proven using this method. Chalcones display 
a large number of different biological activities, such as antibacterial, antifungal, anti-cancer, anti-inflammatory, analgesic, antiviral, anti-malarial, antipyretic and cytotoxic activities. $^{20,21}$

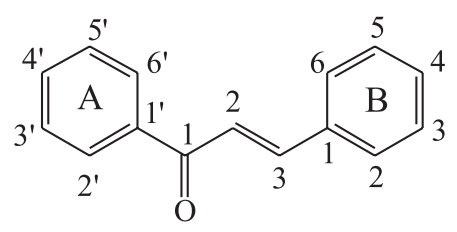

Figure 1. Representative structure of the chalcone backbone.

Multi-drug resistance is one of the major causes of the alarming level of infectious diseases worldwide. The discovery of new drugs with potent antimicrobial activity, particularly against the resistant strains, is, therefore, highly needed. In addition, since many of the currently available antifungal drugs have undesirable side effects, are ineffective against new or re-emerging fungi, or develop a rapid resistance in the pathogen, ${ }^{22}$ there is an urgent need of a next generation of new antifungal agents that can overcome the above disadvantages. Several reports highlighting the significance of chalcones as antimicrobial and antiparasitic agents have been documented in the literature. ${ }^{21}$ Chalcone derivatives with $-\mathrm{OH}$ and $-\mathrm{OCH}_{3}$ in the rings $\mathrm{A}$ and $\mathrm{B}$ have demonstrated potential antileishmanial and anti-trypanosomal activities by acting on a number of molecular targets. ${ }^{23}$

Fungal plant pathogens such as Botrytis cinerea (B. cinerea), ${ }^{24}$ Gibberella fujikuroi (G. fujikuroi) $)^{25}$ and Phytophthora cinnamomi (P. cinnamomi) $)^{26,27}$ attack a wide range of agriculturally and ornamentally important plants ${ }^{28}$ and significantly affect the economy of developing countries causing large economic losses in agriculture. ${ }^{29}$ Numerous fungicides such as carboxin, captan, thiram, tebuconazole and metalaxyl have been used to control fungal phytopathogens, but all of them possess secondary effects in other non-target microorganisms and living beings. ${ }^{30}$ Natural and synthetic chalcones with $-\mathrm{OH}$ and $-\mathrm{OCH}_{3}$ groups linked to different positions of the $\mathrm{A}$ and $\mathrm{B}$ rings have shown bactericidal, antifungal, anthelmintic, insecticidal, insect antifeedant, antiviral and phytotoxic activities. $^{31}$

Plant pathogenic bacteria cause serious problems for industrial agriculture because they affect crops of nutritional and commercial interest. Agrobacterium tumefaciens (A. tumefaciens), Pseudomonas syringae (P. syringae) and Erwinia carotovora (E. carotovora) are Gram-negative bacteria that are responsible for a number of economically important diseases. These bacteria usually infect a wide variety of fruits, vegetables, and ornamental plants, ${ }^{32-34}$ and different types of compounds have been used for their control. However, these control efforts have not always been successful and less toxic new products to replace the existing ones are highly needed. To achieve this goal, the worldwide trend is to explore new compounds against these phytopathogens in order to minimize the risks associated with the development of pathogen populations insensitive to these chemical compounds. ${ }^{35}$ Also, many countries have limited the use of some commercial antimicrobials based on recommendations from the Codex Alimentarius ${ }^{36}$ according to the maximum residue limits (MRLs) for residues of pesticides or veterinary drugs in foods.

Endogenous free-radical species like reactive oxygen (ROS) and nitrogen species (RNS) and other reactive small molecules have emerged as important regulators of many physiological and pathological processes. ROS and RNS are essential to maintain homeostasis and health of human beings, but uncontrolled and excess ROS/RNS have been implicated in the pathogenesis of various diseases including cancer, cardiovascular and neurodegenerative diseases as well as ageing. The human organism has developed defense systems to neutralize excessive levels of ROS and RNS and compensate for the oxidative stress. ${ }^{37}$ When endogenous antioxidant protection is not able to maintain the proper balance of free radicals due to their unlimited or uncontrolled production, several health problems appear. In such cases, additional external antioxidants are required to restore the proper balance between free radicals and antioxidants in the body. ${ }^{38}$ Chalcone derivatives with an $-\mathrm{OH}$ substituent on ring $\mathrm{A}$, and $-\mathrm{SCH}_{3}$ and $-\mathrm{OCH}_{3}$ groups at the para position of ring $\mathrm{B}$ showed good anti-oxidant activity. ${ }^{21}$

Different natural or synthetic chalcones has been studied for their anticancer activities because they exert cytotoxicity through multiple mechanisms, which include cell cycle disruption as well as inhibition of angiogenesis, tubulin polymerization, apoptosis and cell signaling. ${ }^{39}$ On the other hand, high expression of 5-lipoxygenase (5-LOX) has been described in cancer cells and its inhibition has been widely characterized to control tumor cell growth. ${ }^{40,41}$ Moreover, ROS also have to be closely linked with tumor initiation, development and progression, by promoting cell survival, cell proliferation and migration. ${ }^{42}$ Thus, inhibition of 5-LOX or the decrease in ROS levels can also have impact on cancer cell survival and/or proliferation. 5-LOX belongs to a group of closely related non-heme iron containing dioxygenases. These enzymes catalyze the addition of molecular oxygen into poly-unsaturated fatty acids (PUFAs) containing cis, cis-1,4-pentadiene structures to give their hydroperoxy derivatives. LOXs are further classified into 5-, 8-, 9-, 11-, 12-, and 15-LOXs 
according to the positional specificity of arachidonate oxygenation. In addition, the 5-LOX is the source of potent pro-inflammatory mediators present in a variety of inflammatory and allergic diseases. ${ }^{43}$ As 5-LOX have been shown to have a major role in the pathogenesis of various inflammatory disorders, including cancer, inhibitors of 5 -LOX will have a wide range of therapeutic applications. ${ }^{44}$ $\mathrm{Di}-O$-prenylated chalcone derivatives have shown to possess good inhibitory potency of 5-LOX (half maximal inhibitory concentration $\left.\left(\mathrm{IC}_{50}\right)=4 \mu \mathrm{M}\right)$, potent antiproliferative effects $\left(50 \%\right.$ growth inhibition $\left.\left(\mathrm{GI}_{50}\right)=9 \mu \mathrm{M}\right)$ on the MCF-7 breast cancer cell line, and no appreciable effects up to $100 \mu \mathrm{M}$ on the immortalized nontumorigenic human epidermal ( $\mathrm{HaCaT})$ cell line. ${ }^{43}$

In this paper, we report a facile synthesis of nine chalcones to evaluate their effects against phytopathogens and human pathogenic bacteria and fungi as possible alternatives to antimicrobials currently in commercial use. Additionally, as endogenous free radicals and human 5-lipoxygenase (5-hLOX) have been shown to have major roles in the pathogenesis of various health problems including cancer, cardiovascular and neurodegenerative diseases and inflammatory disorders, the chalcones were tested as 5-hLOX inhibitors and DPPH (2,2-diphenyl1-picrylhydrazyl) radical scavengers.

\section{Results and Discussion}

\section{Synthesis}

Chalcones 11-19 were obtained in poor to good yields (11-90\%) via Claisen-Schmidt condensation of acetophenones 1-6 with benzaldehydes 7-10 in acidic or alkaline media (Scheme 1). Acidic medium was mostly preferred when one or more free hydroxyl groups are bound to the aromatic system of the chalcones. When Claisen-Schmidt condensations using other 2'-hydroxy or 2'-methoxy acetophenones were conducted in acidic conditions, chalcones were not produced (12 and 19). This was probably due to either the hydrogen-bond formed by the $\mathrm{OH}$ or OMe groups on C-2' with the carbonyl group (that could hinder the formation of the enol intermediate) or by problems of steric hindrance with the 2'-methoxyl group.

The yields of all the synthesized chalcones were similar or better than those reported in the literature and all were obtained in only one step. Chalcone $\mathbf{1 2}$ is the only new molecule in the series. The solid-state reactions (without solvent) were not attempted.

The synthesis of chalcones with a hydroxyl group in 4-position was incompatible with alkaline medium, except for 12. Chalcones with 2'-OH group can be synthesized in alkaline medium, but with low yield (11\% for 19). Protecting groups resistant to alkaline medium (i.e., methoxymethyl (MOM), tetrahydropyranyl (THP)) should be considered to obtain chalcones in good yields with two or more free hydroxyl groups. Chalcones with 3,4-diOH substituents (catechol group) on the B ring can be synthesized in acid condition with moderate yields (47\% for $\mathbf{1 1}$ and $57 \%$ for $\mathbf{1 8}$ ).

In vitro antibacterial effects of chalcones 11-19 on bacteria pathogenic to humans

Determination of the minimum inhibitory concentration (MIC) of the chalcones against bacteria

The result of the bacterial growth inhibition test (Table 1) showed that chalcones $\mathbf{1 1}$ and $\mathbf{1 8}$ were active<smiles>[R]c1c([R])c([R])c(C(C)=O)c([R])c1[R]</smiles>

1 - 6<smiles>[R]c1c([R])c([R])c(C=O)c([R])c1[R]</smiles>

$7 \mathrm{R}_{6}=\mathrm{R}_{7}=\mathrm{R}_{10}=\mathrm{H}, \mathrm{R}_{8}=\mathrm{R}_{9}=\mathrm{OH}$ $8 \mathrm{R}_{6}=\mathrm{R}_{7}=\mathrm{R}_{10}=\mathrm{H}, \mathrm{R}_{8}=\mathrm{OH}, \mathrm{R}_{9}=\mathrm{OCH}_{3}$ $9 \mathrm{R}_{6}=\mathrm{R}_{7}=\mathrm{R}_{8}=\mathrm{R}_{9}=\mathrm{R}_{10}=\mathrm{H}$ $10 \mathrm{R}_{6}=\mathrm{R}_{10}=\mathrm{H}, \mathrm{R}_{7}=\mathrm{R}_{8}=\mathrm{R}_{9}=\mathrm{OCH}_{3}$<smiles>[R]c1c([R])c([R])c(/C=C/C(=O)c2c([R])c([R])c([R])c([R])c2[R])c([R])c1[R4]</smiles>

$11-19$

$$
\begin{aligned}
& 1 \mathrm{R}_{1}=\mathrm{H}, \mathrm{R}_{2}=\mathrm{R}_{3}=\mathrm{R}_{4}=\mathrm{OCH}_{3}, \mathrm{R}_{5}=\mathrm{H} \\
& 2 \mathrm{R}_{1}=\mathrm{R}_{3}=\mathrm{R}_{4}=\mathrm{H}, \mathrm{R}_{2}=\mathrm{R}_{5}=\mathrm{OCH}_{3} \\
& 3 \mathrm{R}_{2}=\mathrm{R}_{4}=\mathrm{R}_{5}=\mathrm{H}, \mathrm{R}_{1}=\mathrm{R}_{3}=\mathrm{OCH}_{3} \\
& 4 \mathrm{R}_{1}=\mathrm{R}_{2}=\mathrm{R}_{5}=\mathrm{H}, \mathrm{R}_{3}=\mathrm{R}_{4}=\mathrm{OCH}_{3} \\
& 5 \mathrm{R}_{1}=\mathrm{R}_{2}=\mathrm{R}_{3}=\mathrm{R}_{4}=\mathrm{R}_{5}=\mathrm{H} \\
& 6 \mathrm{R}_{2}=\mathrm{R}_{4}=\mathrm{R}_{5}=\mathrm{H}, \mathrm{R}_{1}=\mathrm{R}_{3}=\mathrm{OH}
\end{aligned}
$$

$$
\begin{aligned}
& 11 \mathrm{R}_{1}=\mathrm{R}_{5}=\mathrm{R}_{6}=\mathrm{R}_{7}=\mathrm{R}_{10}=\mathrm{H}, \mathrm{R}_{2}=\mathrm{R}_{3}=\mathrm{R}_{4}=\mathrm{OCH}_{3}, \mathrm{R}_{8}=\mathrm{R}_{9}=\mathrm{OH}(\mathrm{i} ; 44 \%) \\
& 12 \mathrm{R}_{1}=\mathrm{R}_{3}=\mathrm{R}_{4}=\mathrm{R}_{6}=\mathrm{R}_{7}=\mathrm{R}_{10}=\mathrm{H}, \mathrm{R}_{2}=\mathrm{R}_{5}=\mathrm{R}_{9}=\mathrm{OCH}_{3}, \mathrm{R}_{8}=\mathrm{OH}(\mathrm{ii} ; 75 \%) \\
& 13 \mathrm{R}_{1}=\mathrm{R}_{5}=\mathrm{R}_{6}=\mathrm{R}_{7}=\mathrm{R}_{10}=\mathrm{H}, \mathrm{R}_{2}=\mathrm{R}_{3}=\mathrm{R}_{4}=\mathrm{R}_{9}=\mathrm{OCH}_{3}, \mathrm{R}_{8}=\mathrm{OH}(\mathrm{i} ; 77 \%) \\
& 14 \mathrm{R}_{2}=\mathrm{R}_{4}=\mathrm{R}_{5}=\mathrm{R}_{6}=\mathrm{R}_{7}=\mathrm{R}_{10}=\mathrm{H}, \mathrm{R}_{1}=\mathrm{R}_{3}=\mathrm{R}_{9}=\mathrm{OCH}_{3}, \mathrm{R}_{8}=\mathrm{OH}(\mathbf{i} ; 70 \%) \\
& 15 \mathrm{R}_{1}=\mathrm{R}_{3}=\mathrm{R}_{4}=\mathrm{R}_{6}=\mathrm{R}_{7}=\mathrm{R}_{8}=\mathrm{R}_{9}=\mathrm{R}_{10}=\mathrm{H}, \mathrm{R}_{2}=\mathrm{R}_{5}=\mathrm{OCH}_{3}(\mathbf{i i} ; 45 \%) \\
& 16 \mathrm{R}_{1}=\mathrm{R}_{2}=\mathrm{R}_{5}=\mathrm{R}_{6}=\mathrm{R}_{7}=\mathrm{R}_{10}=\mathrm{H}, \mathrm{R}_{3}=\mathrm{R}_{4}=\mathrm{R}_{9}=\mathrm{OCH}_{3}, \mathrm{R}_{8}=\mathrm{OH}(\mathrm{i} ; 90 \%) \\
& 17 \mathrm{R}_{1}=\mathrm{R}_{2}=\mathrm{R}_{3}=\mathrm{R}_{4}=\mathrm{R}_{5}=\mathrm{R}_{6}=\mathrm{R}_{7}=\mathrm{R}_{10}=\mathrm{H}, \mathrm{R}_{8}=\mathrm{OH}, \mathrm{R}_{9}=\mathrm{OCH}(\mathrm{i} ; 48 \%) \\
& 18 \mathrm{R}_{1}=\mathrm{R}_{2}=\mathrm{R}_{3}=\mathrm{R}_{4}=\mathrm{R}_{5}=\mathrm{R}_{6}=\mathrm{R}_{7}=\mathrm{R}_{10}=\mathrm{H}, \mathrm{R}_{8}=\mathrm{R}_{9}=\mathrm{OH}(\mathrm{i} ; 57 \%) \\
& 19 \mathrm{R}_{2}=\mathrm{R}_{4}=\mathrm{R}_{5}=\mathrm{R}_{6}=\mathrm{R}_{10}=\mathrm{H}, \mathrm{R}_{1}=\mathrm{R}_{3}=\mathrm{OH}, \mathrm{R}_{7}=\mathrm{R}_{8}=\mathrm{R}_{9}=\mathrm{OCH}_{3}(\mathrm{ii} ; 11 \%)
\end{aligned}
$$

Scheme 1. Preparation of chalcones 11-19 via Claisen-Schmidt condensation in acidic ( $i$ : $\left.\mathrm{SOCl}_{2} / \mathrm{EtOH}\right)$ and alkaline $\left(i i: \mathrm{KOH} / \mathrm{MeOH} / \mathrm{H}_{2} \mathrm{O}\right) \mathrm{media}$. Methodologies and yields of reaction are shown in brackets. 
Table 1. Results of the in vitro antibacterial assay

\begin{tabular}{|c|c|c|c|c|c|}
\hline \multirow[b]{2}{*}{ Compound } & \multirow[b]{2}{*}{ Structure } & \multicolumn{4}{|c|}{ Minimum inhibitory concentration (MIC) $/\left(\mu \mathrm{g} \mathrm{mL}^{-1}\right)$} \\
\hline & & $\begin{array}{c}\text { E. coli } \\
\text { ATCC25922 }\end{array}$ & $\begin{array}{c}\text { E. coli } \\
33.1\end{array}$ & $\begin{array}{c}\text { S. aureus } \\
\text { NTCC8325-4 }\end{array}$ & $\begin{array}{l}\text { S. aureus } \\
\text { MRSA } 97-7\end{array}$ \\
\hline 11 & & $>100$ & $>100$ & 70 & 100 \\
\hline 12 & & $>100$ & $>100$ & $>100$ & $>100$ \\
\hline 13 & & $>100$ & $>100$ & $>100$ & $>100$ \\
\hline 14 & & $>100$ & $>100$ & $>100$ & $>100$ \\
\hline 15 & & $>100$ & $>100$ & $>100$ & $>100$ \\
\hline 16 & & $>100$ & $>100$ & $>100$ & $>100$ \\
\hline 17 & & $>100$ & $>100$ & $>100$ & $>100$ \\
\hline 18 & & $>100$ & $>100$ & 50 & 50 \\
\hline 19 & & $>100$ & $>100$ & $>100$ & $>100$ \\
\hline Methicillin & & - & - & 5 & 50 \\
\hline Ciprofloxacin & & 1 & 50 & 10 & 80 \\
\hline Ampicillin & & 60 & $>100$ & - & - \\
\hline
\end{tabular}

Antibacterial activity of chalcones in reference strain E. coli ATCC25922, multi-resistant E. coli 33.1, reference strain S. aureus NTCC8325-4 and methicillin-resistant $S$. aureus MRSA 97-7 isolates.

against sensitive $S$. aureus strains with MICs of 50 and $70 \mu \mathrm{g} \mathrm{mL}^{-1}$, respectively. These compounds also inhibited the growth of MRSA 97-7 strain (MICs of 50 and $90 \mu \mathrm{gL}^{-1}$, respectively).

When comparing the structural characteristics of $\mathbf{1 1}$ and 18, which are weakly active against $S$. aureus with the rest of the chalcones, it can be observed that both compounds possess a catechol moiety in their structures, which could play a key role in the activity. Then, our results indicated that the presence of catechol group at positions 3,4 on the B ring is necessary to exhibit the anti-staphylococcal activity, decreasing this activity when the hydroxyl at position 3 
is methylated (chalcones 11, 13, 14, 16 and 17). These results are similar to those obtained by Batovska et al. ${ }^{45}$ who reported that the presence of hydroxyl group on ring $\mathrm{B}$ alone is not enough for the chalcones to exhibit antistaphylococcal activity and the introduction of a methoxy group next to $o$ - and $p$-hydroxyl groups led to more inactive chalcones, while the activity was kept when the methoxy group was inserted next to the $m$-hydroxyl group. They also showed that the lipophilicity of ring A is important for the antibacterial activity against $S$. aureus.

Chalcones with hydroxyl and methylthio groups on B ring at position 4 are being considered for a next work.

\section{Evaluation of the ability of chalcones 11 and 18 to potentiate the antibiotic activity of methicillin}

The detection of what are known as resistancemodifying agents (RMAs) represents an attractive strategy to mitigate the spread of bacterial drug resistance, since it could facilitate the recycling of well-established antibiotics. ${ }^{46}$ Drug repositioning can accelerate the drug development process as the already established compounds are characterized by known safety profiles, pharmacology and administration routes..$^{47,48}$

Chalcones 11 and 18 showed an important capacity to reduce the MIC of methicillin against MRSA 97-7, re-sensitizing these resistant bacteria 2,500 times methicillin and 2.5 times the synthetic chalcone 18. Compound $\mathbf{1 8}$ was found to act synergistically in conjunction with the commercial antibiotic (Table 2), while compound $\mathbf{1 1}$ showed only partial synergy, although the dose was reduced by the same amount as $\mathbf{1 8}$.

These findings add new data to the previously reported ${ }^{49}$ enhancing capacity of chalcones to antibiotics activity showing that five chalcones possessing either 2-OH or $4-\mathrm{OH}$ on the $\mathrm{B}$ ring enhanced the antibacterial activity of the non $\beta$-lactam antibiotics doxycycline, ciprofloxacin and/or gentamicin. In the present paper, the 3,4-diOH chalcones either unsubstituted (18) or 3',4',5'-trimethoxylated (11) on the A ring, showed potentiated activity of the $\beta$-lactam antibiotic methicillin.
In vitro antifungal effects on fungi pathogenic to humans

In the last decades, fungi have emerged as major causes of human morbidity and mortality, mainly among the immunocompromised and seriously-ill hospitalized patients. ${ }^{50}$ Most of these mycoses-related deaths were associated with Candida albicans (C. albicans) and Cryptococcus neoformans (C. neoformans) and, although there are several antifungal drugs in clinical use to treat both opportunistic fungal species, fungal infections remain very difficult to eradicate.

Since chalcones with different substituents than the ones synthesized here have shown antifungal activities in several previous papers, ${ }^{51-58}$ the antifungal properties of these compounds could add new interesting data on the antifungal behavior of chalcones. Thus, the nine chalcones 11-19 were tested for antifungal properties against the clinically important yeasts $C$. albicans (ATCC 10231) and C. neoformans (ATCC 32264). To assess antifungal activities, the broth microdilution method M27-A3 for yeasts of the Clinical and Laboratory Standards Institute (CLSI) ${ }^{59}$ was used.

The percentage of inhibition of each fungus was determined for each compound at two-fold dilutions in the range 250-3.9 $\mu \mathrm{g} \mathrm{mL}^{-1}$ (Table 3). In the right column, $\mathrm{IC}_{50}$ represents the minimum concentration that inhibits fungal growth by $50 \%$. This value is accepted in the literature as representative of the in vitro activity of target compounds. ${ }^{60}$

Although Table 3 shows that all compounds inhibit both $C$. albicans and $C$. neoformans at different tested concentrations, it is interesting to note that $C$. albicans is more sensitive than $C$. neoformans. In Table 3 , it can be observed that $\mathrm{IC}_{50}$ of all compounds against C. albicans ranged from 125 to $>250 \mu \mathrm{g} \mathrm{mL} \mathrm{mL}^{-1}$, with five compounds $(\mathbf{1 1}, \mathbf{1 2}, \mathbf{1 4}, 16$ and 19) possessing an $\mathrm{IC}_{50} \geq 250 \mu \mathrm{g} \mathrm{mL}^{-1}$, one (13) with $\mathrm{IC}_{50}=250 \mu \mathrm{g} \mathrm{mL}^{-1}$, two (15 and 18) displaying $\mathrm{IC}_{50}=125 \mu \mathrm{g} \mathrm{mL} \mathrm{m}^{-1}$ and one (17) with $\mathrm{IC}_{50}=50 \mu \mathrm{g} \mathrm{mL}^{-1}$. In the case of $C$. neoformans the $\mathrm{IC}_{50}$ ranged from 7.8 to $>250 \mu \mathrm{g} \mathrm{mL}^{-1}$ with two compounds (15 and 17) displaying an $\mathrm{IC}_{50}$ between 7.8-15.6 $\mathrm{g} \mathrm{mL}^{-1}$,

Table 2. Synergistic effects of chalcones $\mathbf{1 1}$ and $\mathbf{1 8}$ with methicillin in MRSA 97-7

\begin{tabular}{|c|c|c|c|c|c|c|c|}
\hline Strain & Drug & $\begin{array}{l}\text { MIC alone / } \\
\left(\mu \mathrm{g} \mathrm{mL}^{-1}\right)\end{array}$ & $\begin{array}{l}\text { MIC combination / } \\
\left(\mu \mathrm{g} \mathrm{mL}^{-1}\right)\end{array}$ & $\begin{array}{l}\text { FICs of each } \\
\text { compound }\end{array}$ & DRI & FICI & Outcome \\
\hline \multirow{4}{*}{ MRSA 97-7 } & 18 & 50 & 20 & 0.40 & 2.5 & \multirow{2}{*}{0.40} & \multirow{2}{*}{ synergy } \\
\hline & methicillin & 50 & 0.02 & 0.0004 & 2,500 & & \\
\hline & 11 & 100 & 50 & 0.5 & 2.0 & \multirow{2}{*}{0.50} & \multirow{2}{*}{ partial synergy } \\
\hline & methicillin & 50 & 0.02 & 0.0004 & 2,500 & & \\
\hline
\end{tabular}

MIC: minimum inhibitory concentration; FIC: fractional inhibitory concentration; DRI: dose reduction index = MIC of each compound alone/MIC in combination; FICI: FIC index. 
Table 3. Percentages of inhibition of chalcones 11-19 against $C$. albicans ATCC $10231(\mathrm{Ca})$ and $C$. neoformans ATCC $32264(\mathrm{Cn})$ at different concentrations. The compounds were ordered by structural similarity in order to facilitate the structure-activity analysis and not in numerical order

\begin{tabular}{|c|c|c|c|c|c|c|c|c|c|c|}
\hline \multirow{2}{*}{ Compound } & \multirow{2}{*}{ Structure } & \multirow{2}{*}{ Fungi } & \multicolumn{8}{|c|}{ Concentration $/\left(\mu \mathrm{gL}^{-1}\right)$} \\
\hline & & & 250 & 125 & 62.5 & 31.2 & 15.6 & 7.8 & 3.9 & $\mathrm{IC}_{50}{ }^{\mathrm{a}}$ \\
\hline 18 & & $\begin{array}{l}\mathrm{Ca} \\
\mathrm{Cn}\end{array}$ & $\begin{array}{l}66.3 \pm 1.9 \\
24.4 \pm 2.1\end{array}$ & $\begin{array}{l}40.6 \pm 0.0 \\
10.9 \pm 2.0\end{array}$ & $\begin{array}{c}24.4 \pm 0.1 \\
0\end{array}$ & $\begin{array}{c}17.8 \pm 0.2 \\
0\end{array}$ & $\begin{array}{c}11.1 \pm 1.9 \\
0\end{array}$ & $\begin{array}{c}8.1 \pm 0.7 \\
0\end{array}$ & $\begin{array}{c}3.6 \pm 0.2 \\
0\end{array}$ & $\begin{array}{c}125 \\
>250\end{array}$ \\
\hline 17 & & $\begin{array}{l}\mathrm{Ca} \\
\mathrm{Cn}\end{array}$ & $\begin{array}{l}100 \\
100\end{array}$ & $\begin{array}{l}100 \\
100\end{array}$ & $\begin{array}{l}100 \\
100\end{array}$ & $\begin{array}{c}45.9 \pm 1.5 \\
100\end{array}$ & $\begin{array}{l}18.2 \pm 0.6 \\
93.5 \pm 0.1\end{array}$ & $\begin{array}{c}8.8 \pm 0.0 \\
15.4 \pm 0.1\end{array}$ & $\begin{array}{l}5.2 \pm 0.5 \\
8.6 \pm 0.4\end{array}$ & $\begin{array}{c}50 \\
15.6\end{array}$ \\
\hline 11 & & $\begin{array}{l}\mathrm{Ca} \\
\mathrm{Cn}\end{array}$ & $\begin{array}{l}25.0 \pm 2.8 \\
45.9 \pm 0.2\end{array}$ & $\begin{array}{l}18.4 \pm 1.6 \\
34.7 \pm 2.7\end{array}$ & $\begin{array}{c}12.6 \pm 0.8 \\
9.1 \pm 0.2\end{array}$ & $\begin{array}{l}8.4 \pm 0.4 \\
7.6 \pm 0.5\end{array}$ & $\begin{array}{l}5.1 \pm 1.0 \\
3.3 \pm 0.5\end{array}$ & $\begin{array}{l}3.4 \pm 0.2 \\
2.8 \pm 0.1\end{array}$ & $\begin{array}{l}2.3 \pm 0.9 \\
1.7 \pm 0.5\end{array}$ & $\begin{array}{l}250 \\
250\end{array}$ \\
\hline 13 & & $\begin{array}{l}\mathrm{Ca} \\
\mathrm{Cn}\end{array}$ & $\begin{array}{l}74.6 \pm 3.3 \\
60.6 \pm 1.6\end{array}$ & $\begin{array}{c}27.51 \pm 1.35 \\
46.6 \pm 0.4\end{array}$ & $\begin{array}{c}10.4 \pm 1.0 \\
0\end{array}$ & $\begin{array}{c}6.7 \pm 0.3 \\
0\end{array}$ & $\begin{array}{c}3.8 \pm 0.7 \\
0\end{array}$ & $\begin{array}{c}2.4 \pm 1.2 \\
0\end{array}$ & $\begin{array}{c}1.8 \pm 0.1 \\
0\end{array}$ & $\begin{array}{l}250 \\
125\end{array}$ \\
\hline 15 & & $\begin{array}{l}\mathrm{Ca} \\
\mathrm{Cn}\end{array}$ & $\begin{array}{c}84.0 \pm 2.7 \\
100\end{array}$ & $\begin{array}{l}54.5 \pm 0.0 \\
95.6 \pm 0.8\end{array}$ & $\begin{array}{l}31.0 \pm 2.3 \\
95.5 \pm 2.9\end{array}$ & $\begin{array}{l}17.0 \pm 2.0 \\
86.3 \pm 0.5\end{array}$ & $\begin{array}{c}8.0 \pm 0.2 \\
75.3 \pm 1.5\end{array}$ & $\begin{array}{c}3.7 \pm 0.0 \\
61.5 \pm 1.0\end{array}$ & $\begin{array}{l}0 \\
0\end{array}$ & $\begin{array}{l}125 \\
7.8\end{array}$ \\
\hline 12 & & $\begin{array}{l}\mathrm{Ca} \\
\mathrm{Cn}\end{array}$ & $\begin{array}{l}27.4 \pm 8.3 \\
86.0 \pm 0.0\end{array}$ & $\begin{array}{l}15.1 \pm 2.1 \\
80.9 \pm 1.9\end{array}$ & $\begin{array}{c}13.5 \pm 0.3 \\
5.5 \pm 0.6\end{array}$ & $\begin{array}{c}9.4 \pm 1.1 \\
0.00\end{array}$ & $\begin{array}{c}4.9 \pm 0.9 \\
0.00\end{array}$ & $\begin{array}{c}3.4 \pm 0.3 \\
0.00\end{array}$ & $\begin{array}{c}2.3 \pm 0.3 \\
0.00\end{array}$ & $\begin{array}{c}>250 \\
125\end{array}$ \\
\hline 14 & & $\begin{array}{l}\mathrm{Ca} \\
\mathrm{Cn}\end{array}$ & $\begin{array}{l}42.3 \pm 2.1 \\
85.6 \pm 2.1\end{array}$ & $\begin{array}{l}30.7 \pm 1.9 \\
66.5 \pm 1.3\end{array}$ & $\begin{array}{l}19.6 \pm 1.5 \\
27.4 \pm 0.0\end{array}$ & $\begin{array}{c}13.5 \pm 1.2 \\
3.2 \pm 0.1\end{array}$ & $\begin{array}{c}8.5 \pm 1.2 \\
0\end{array}$ & $\begin{array}{c}6.0 \pm 0.9 \\
0\end{array}$ & $\begin{array}{c}3.6 \pm 0.0 \\
0\end{array}$ & $\begin{array}{c}>250 \\
125\end{array}$ \\
\hline 16 & & $\begin{array}{l}\mathrm{Ca} \\
\mathrm{Cn}\end{array}$ & $\begin{array}{c}27.1 \pm 1.3 \\
100\end{array}$ & $\begin{array}{l}15.3 \pm 0.9 \\
85.8 \pm 0.0\end{array}$ & $\begin{array}{l}12.1 \pm 0.6 \\
77.1 \pm 1.3\end{array}$ & $\begin{array}{c}8.2 \pm 0.7 \\
45.5 \pm 0.1\end{array}$ & $\begin{array}{c}6.2 \pm 0.1 \\
32.0 \pm 0.5\end{array}$ & $\begin{array}{c}2.5 \pm 0.8 \\
19.9 \pm 0.0\end{array}$ & $\begin{array}{c}0.2 \pm 0.5 \\
14.8 \pm 0.2\end{array}$ & $\begin{array}{l}>250 \\
31.25\end{array}$ \\
\hline 19 & & $\begin{array}{l}\mathrm{Ca} \\
\mathrm{Cn}\end{array}$ & $\begin{array}{l}18.4 \pm 1.6 \\
23.7 \pm 0.5\end{array}$ & $\begin{array}{c}11.0 \pm 0.8 \\
7.1 \pm 3.7\end{array}$ & $\begin{array}{c}5.9 \pm 0.2 \\
0\end{array}$ & $\begin{array}{c}5.1 \pm 0.2 \\
0\end{array}$ & $\begin{array}{c}2.6 \pm 0.0 \\
0\end{array}$ & $\begin{array}{c}1.8 \pm 0.3 \\
0\end{array}$ & $\begin{array}{c}1.6 \pm 0.1 \\
0\end{array}$ & $\begin{array}{l}>250 \\
>250\end{array}$ \\
\hline Amphotericin B & & $\begin{array}{l}\mathrm{Ca} \\
\mathrm{Cn}\end{array}$ & $\begin{array}{l}100 \\
100\end{array}$ & $\begin{array}{l}100 \\
100\end{array}$ & $\begin{array}{l}100 \\
100\end{array}$ & $\begin{array}{l}100 \\
100\end{array}$ & $\begin{array}{l}100 \\
100\end{array}$ & $\begin{array}{l}100 \\
100\end{array}$ & $\begin{array}{l}100 \\
100\end{array}$ & $\begin{array}{l}1.5 \\
1.0\end{array}$ \\
\hline
\end{tabular}

${ }^{{ }^{a} \mathrm{IC}_{50}}$ value represents the concentration of each compound that inhibits fungal growth by $50 \%$.

one compound (16) with an $\mathrm{IC}_{50}=31.25 \mu \mathrm{g} \mathrm{mL} \mathrm{mL}^{-1}$, three compounds with $\mathrm{IC}_{50} \geq 125 \mu \mathrm{g} \mathrm{mL} \mathrm{L}^{-1}(\mathbf{1 2}, \mathbf{1 3}$ and $\mathbf{1 4})$ and only two compounds (11 and 18) with $\mathrm{IC}_{50}>250 \mu \mathrm{g} \mathrm{mL} \mathrm{L}^{-1}$.

The comparative behavior of all compounds against C. albicans and C. neoformans can be clearly corroborated by comparing the dose-responses curves in Figure 2.

Against C. albicans (Figure 2a), four (13, 15, 17 and 18) out of the nine compounds produced an inhibition $\geq 50 \%$ at $250 \mu \mathrm{g} \mathrm{mL}^{-1}$, one $(\mathbf{1 5})$ produces $\geq 50 \%$ inhibition at
$125 \mu \mathrm{g} \mathrm{mL}-1$ and one (17) at $50 \mu \mathrm{g} \mathrm{mL}-1$. While, against C. neoformans, six compounds (12-17) produced an inhibition $\geq 50 \%$ at $250 \mu \mathrm{g} \mathrm{mL}^{-1}$ and five of them (12, 14-17) produced the same inhibition at $125 \mu \mathrm{g} \mathrm{mL}-1$ (Figure 2b).

To see the influence of the methylation of the $3-\mathrm{OH}$ group (on the B ring) on the growth of $C$. neoformans, the anticryptococcal activity of $\mathbf{1 8}$ (with 3,4-diOH on the B ring) was compared with 17 (with 3-OMe, 4-OH on the B ring), 

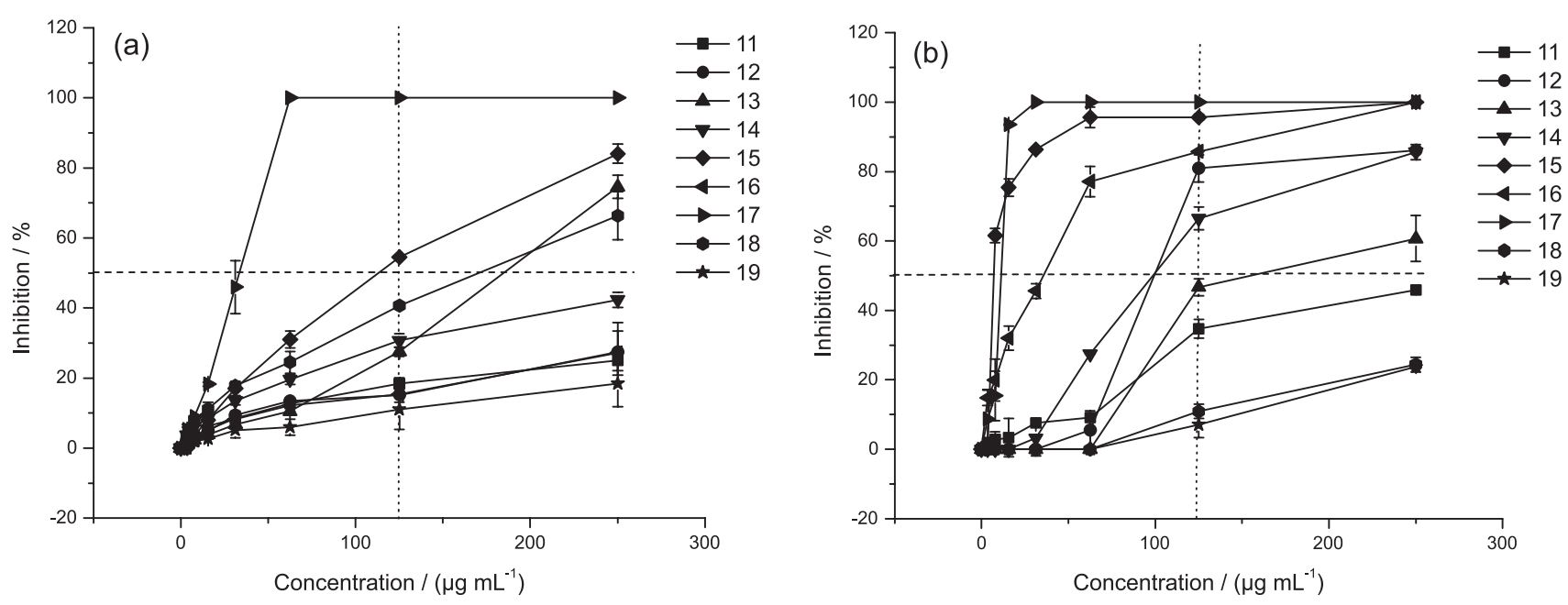

Figure 2. Comparative antifungal activities of chalcones 11-19 against (a) C. albicans; (b) C. neoformans. The horizontal dotted line was drawn to clearly see the number of compounds that displayed $\geq 50 \%$ inhibition of fungal growth. The vertical dotted lines were drawn to clearly see the effects of the different compounds at $125 \mu \mathrm{g} \mathrm{mL}{ }^{-1}$.

both with an un-substituted ring A (Figure 3a). With the same purpose, the anticryptococcal activity of $\mathbf{1 1}$ (with 3,4-diOH on the $\mathrm{B}$ ring) was compared with $\mathbf{1 3}$ (with 3-OMe, 4-OH on the $\mathrm{B}$ ring), both with three methoxyl groups on the A ring (Figure 3b). Results clearly show that the methylation of the 3-OH increased the activity in different degrees on the A ring unsubstituted and substituted chalcones. However, in the compounds with an unsubstituted $\mathrm{A}$ ring the difference in inhibition between $\mathbf{1 7}$ and $\mathbf{1 8}$ (Figure 3a) was much greater than that observed between $\mathbf{1 1}$ and $\mathbf{1 3}$ (Figure 3b), showing that the substitution of ring A could play an important role in the activity.

To see the influence of different substituents on ring A on the anticryptococcal activity, all compounds possessing 3-OMe, 4-OH substituents on the B ring (12-14, 16, 17) were compared in Figure 4.

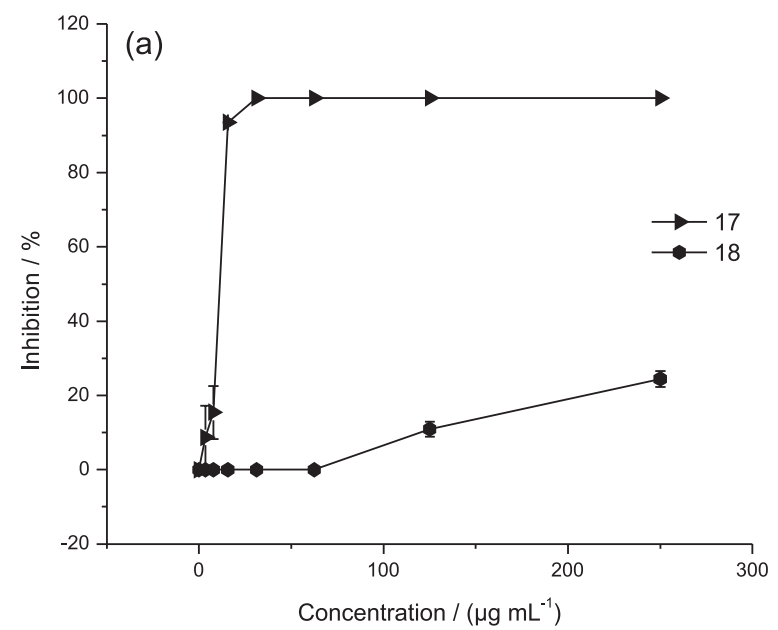

From Figure 4, it is clear that the chalcone with 3-OMe, 4-OH substituents and unsubstituted-ring A chalcone (17) displayed the best activity reaching the highest inhibition (100\%) at $7.8 \mu \mathrm{g} \mathrm{mL}$. The activity decreases in the following order: 17 (unsubstituted-ring A) $>16\left(3^{\prime}, 4^{\prime}-(\mathrm{MeO})_{2}\right.$ A ring $)>12\left(2^{\prime} 5^{\prime}-(\mathrm{MeO})_{2}\right.$ A ring $)$ $>14\left(2^{\prime}, 4^{\prime}-(\mathrm{MeO})_{2} \mathrm{~A}\right.$ ring $)>13\left(3^{\prime}, 4^{\prime}, 5^{\prime}-(\mathrm{MeO})_{3} \mathrm{~A}\right.$ ring $)$.

In addition, the $(\mathrm{MeO})_{2}$ derivatives possessing one of the methoxyl groups at position 2' (12 and 14) displayed lower activities than $\mathbf{1 6}\left(3^{\prime}, 4^{\prime}-(\mathrm{MeO})_{2}\right.$ derivative), probably due to steric hindrance of the $\mathrm{OMe}$ at position 2'.

Our results showed that these chalcones were more active against $C$. neoformans than against $C$. albicans. Regarding the relation between structure and anticryptococcal activity, the methylation of the 3-OH of the B-ring led to an improved activity. In turn, the pattern of substitution of

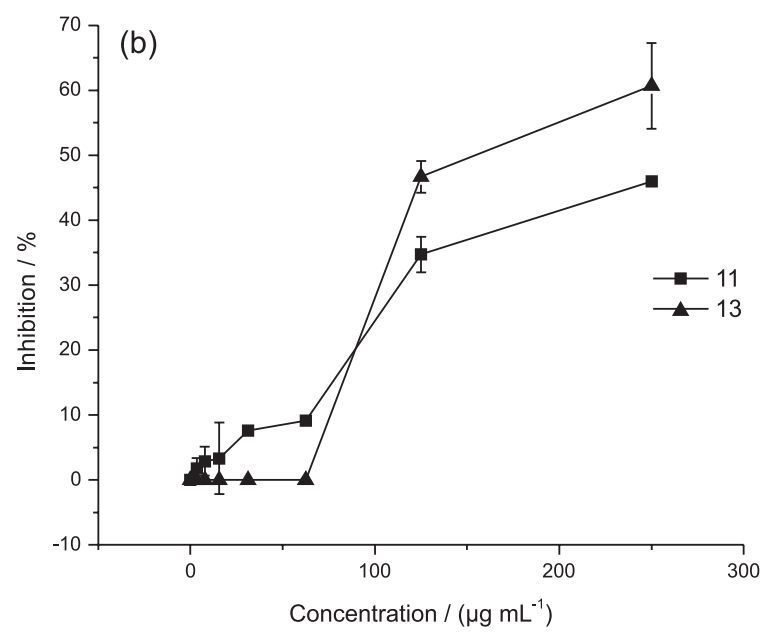

Figure 3. Influence of the methylation of the 3-OH group on ring B on growth of $C$. neoformans, when ring A is (a) unsubstituted (chalcones $\mathbf{1 7}$ and $\mathbf{1 8}$ ) or (b) trimethoxysubstituted (chalcones 11 and 13). Chalcones 18 and $\mathbf{1 3}$ possess 3,4-diOH as substituents on the B ring and chalcones $\mathbf{1 7}$ and $\mathbf{1 1}$ possess 3-OMe, 4-OH substituents on the B ring. 


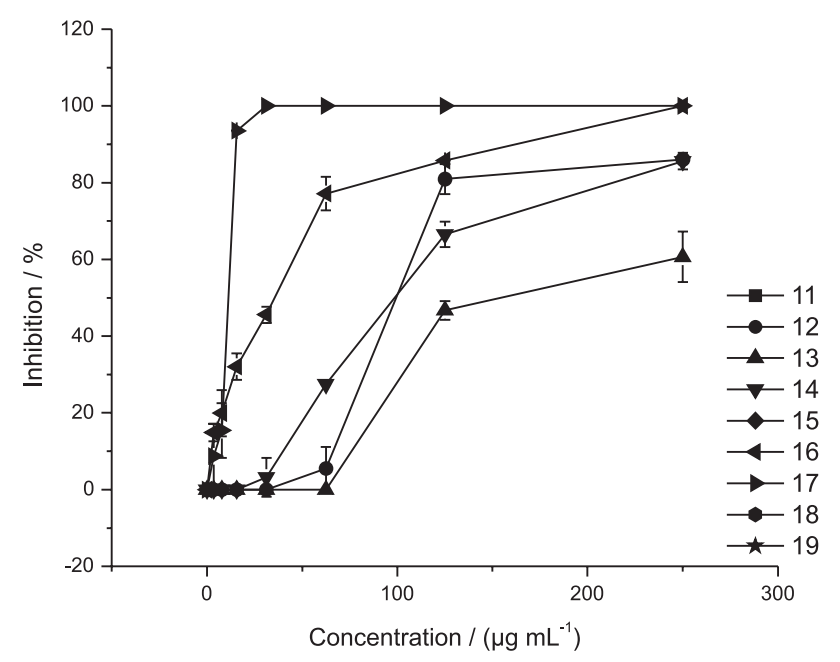

Figure 4. Comparative anticryptococcal activity of 3-OMe, 4-OH chalcones with different substituents on ring A [unsubstituted (17); $3^{\prime}, 4^{\prime}, 5^{\prime}-(\mathrm{OMe})_{3}(\mathbf{1 3}) ; 2^{\prime}, 4^{\prime}-(\mathrm{OMe})_{2}(\mathbf{1 4}), 2^{\prime}, 5^{\prime}-(\mathrm{OMe})_{2}(\mathbf{1 2}), 3^{\prime}, 4^{\prime}-(\mathrm{OMe})_{2}$ (16)].

the A ring appears to play some role in the anticryptococcal activity.

\section{In vitro antibacterial effects on bacteria pathogenic to plants}

Results of the antibacterial assays (Table 4) indicate an outstanding antibacterial activity of compound $\mathbf{1 2}$ on the growth of $P$. syringae with a low $\mathrm{IC}_{50}$ value $(8 \mu \mathrm{M}$ or $2.5 \mu \mathrm{g} \mathrm{mL}^{-1}$ ). This effect is similar to that observed with streptomycin whose $\mathrm{IC}_{50}$ value is close to $5 \mu \mathrm{M}$ $\left(2.9 \mu \mathrm{g} \mathrm{mL}^{-1}\right)$. Although the best inhibitory effect was observed in the previous case, the remaining compounds of the list do not show activity or show a moderate effect (i.e., 19 shows an $\mathrm{IC}_{50}=191 \mu \mathrm{M}$ and $\mathbf{1 7}, \mathrm{IC}_{50}=343 \mu \mathrm{M}$ ) only against $P$. syringae. The other two phytopathogenic bacteria

Table 4. $\mathrm{IC}_{50}$ values of chalcones towards phytopathogenic bacteria

\begin{tabular}{lccc}
\hline \multirow{2}{*}{ Compound } & \multicolumn{3}{c}{$\mathrm{IC}_{50} / \mu \mathrm{M}$} \\
\cline { 2 - 4 } & A. tumefaciens & E. carotovora & P. syringae \\
\hline $\mathbf{1 1}$ & $>500$ & 500 & 457 \\
$\mathbf{1 2}$ & $>500$ & $>500$ & 8 \\
$\mathbf{1 3}$ & $>500$ & $>500$ & $>500$ \\
$\mathbf{1 4}$ & $>500$ & $>500$ & $>500$ \\
$\mathbf{1 5}$ & $>500$ & $>500$ & $>500$ \\
$\mathbf{1 6}$ & 392 & $>500$ & 494 \\
$\mathbf{1 7}$ & $>500$ & $>500$ & 500 \\
$\mathbf{1 8}$ & $>500$ & $>500$ & 343 \\
$\mathbf{1 9}$ & 500 & 442 & 191 \\
\hline
\end{tabular}

Antibacterial activities are shown as $\mathrm{IC}_{50}$ values in $\mu \mathrm{M}$ concentrations; $\mathrm{IC}_{50}$ values were calculated from the first kinetic assay. were less sensitive to the compounds. However, some sensitivity was observed in the presence of compound $\mathbf{1 6}$ for A. tumefaciens, and in the presence of the compound 19 against $E$. carotovora and $P$. syringae.

Chalcones 19 and 12 showed an interesting effect on $P$. syringae that is a Gram-negative bacterium, which is classified as pathovars according to its host specificity. Infection with this pathogen produces important economic losses that may affect seriously the net production as well as the quality of the product obtained.

\section{In vitro fungicidal effects on fungi pathogenic to plants}

The results of the antifungal activity assay using phytopathogens (Table 5) indicate a high sensitivity to the chalcones, with growth inhibition percentages higher than $51 \%$, at all concentrations tested. Although the positive controls, based on commercial antifungal agents (pure active ingredients), showed strong inhibition (100\%) at all concentrations tested in the assays, some chalcones showed inhibition values similar or slightly lower on the growth of the oomycete $P$. cinnamomi (for the case of compound 15) and G. fujikuroi (for the case of compounds 14, 15 and 17). This difference was statistically significant with respect to the negative control. The foregoing indicates that this type of compound may have great potential for the treatment of these pathogens. Compound $\mathbf{1 5}$ was the most active of this series inhibiting the growth of the two fungi (B. cinerea and G. fujikuroi) and the oomycete (P. cinnamomi). P. cinnamomi was the pathogen most sensitive to $\mathbf{1 5}$, registering $100 \%$ growth inhibition with the lowest concentration tested $(250 \mu \mathrm{M})$, achieving effects similar to those observed with metalaxyl.

Additionally, an interesting sensitivity of the fungus G. fujikuroi was observed compared to the complete series of chalcones, with percentages of inhibition higher than $75.8 \%$.

\section{In vitro 5-hLOX enzyme assay}

Three chalcones displayed an interesting activity as human 5-hLOX inhibitors (Table 6). The analysis of the relationship between structure and activity showed that the most potent inhibitors $\mathbf{1 1}, \mathbf{1 8}$, and $\mathbf{1 9}$ possess free hydroxyl groups on the A ring (19) or catechol groups on the B ring (11 and 18) in the structure. The docking studies (Figure 5) revealed that the catechol group present in chalcone $\mathbf{1 8}$ was oriented towards the metal, which agrees with a competitive mechanism found in a kinetics experiment (Figure 6). Compound 11, which was the best inhibitor found, presented a mixed mechanism and was unable to orient the catechol 
Table 5. Percentage of growth inhibition of phytopathogenic fungi

\begin{tabular}{|c|c|c|c|c|c|c|c|c|c|}
\hline \multirow{3}{*}{ Compound } & \multicolumn{9}{|c|}{ Mycelial growth inhibition of fungal plant pathogens / \% } \\
\hline & \multicolumn{3}{|c|}{ P. cinnamomi } & \multicolumn{3}{|c|}{ B. cinerea } & \multicolumn{3}{|c|}{ G. fujikuroi } \\
\hline & $250 \mu \mathrm{M}$ & $500 \mu \mathrm{M}$ & $1000 \mu \mathrm{M}$ & $250 \mu \mathrm{M}$ & $500 \mu \mathrm{M}$ & $1000 \mu \mathrm{M}$ & $250 \mu \mathrm{M}$ & $500 \mu \mathrm{M}$ & $1000 \mu \mathrm{M}$ \\
\hline 11 & $60.14 \pm 1.26$ & $66.67 \pm 1.26$ & $68.84 \pm 1.26$ & $56.65 \pm 0.97$ & $66.28 \pm 0.63$ & $55.96 \pm 0.0$ & $77.11 \pm 1.45$ & $83.28 \pm 1.21$ & $85.30 \pm 2.35$ \\
\hline 12 & $64.13 \pm 1.09$ & $67.75 \pm 1.66$ & $73.55 \pm 0.63$ & $51.83 \pm 1.95$ & $69.27 \pm 0.79$ & $50.46 \pm 0.0$ & $79.54 \pm 1.37$ & $81.09 \pm 0.65$ & $83.29 \pm 0.61$ \\
\hline 13 & $61.23 \pm 0.63$ & $64.13 \pm 1.09$ & $69.20 \pm 2.26$ & $60.09 \pm 1.95$ & $67.66 \pm 0.97$ & $71.56 \pm 0.79$ & $78.36 \pm 0.69$ & $81.39 \pm 2.91$ & $83.89 \pm 3.23$ \\
\hline 14 & $69.57 \pm 1.09$ & $82.97 \pm 0.77$ & $100 \pm 0.0$ & $50.92 \pm 0.79$ & $72.94 \pm 0.79$ & $100 \pm 0.0$ & $84.64 \pm 2.04$ & $87.58 \pm 0.91$ & $85.96 \pm 2.19$ \\
\hline 15 & $100 \pm 0.0$ & $100 \pm 0.0$ & $100 \pm 0.0$ & $69.27 \pm 0.79$ & $72.02 \pm 0.79$ & $76.15 \pm 0.79$ & $85.02 \pm 0.57$ & $86.97 \pm 0.54$ & $88.20 \pm 0.52$ \\
\hline 16 & $65.58 \pm 1.66$ & $74.64 \pm 0.63$ & $81.16 \pm 1.26$ & $60.09 \pm 1.95$ & $53.26 \pm 0.07$ & $73.39 \pm 1.59$ & $77.11 \pm 1.45$ & $82.21 \pm 0.63$ & $84.34 \pm 0.59$ \\
\hline 17 & $63.77 \pm 1.26$ & $73.55 \pm 0.63$ & $75.36 \pm 1.26$ & $57.34 \pm 1.95$ & $74.77 \pm 0.79$ & $74.77 \pm 5.55$ & $89.06 \pm 0.98$ & $91.38 \pm 0.54$ & $82.44 \pm 3.65$ \\
\hline 18 & $59.06 \pm 1.66$ & $67.03 \pm 1.66$ & $74.28 \pm 1.66$ & $51.38 \pm 1.59$ & $59.63 \pm 1.56$ & $67.89 \pm 1.59$ & $79.92 \pm 1.79$ & $80.71 \pm 0.65$ & $81.46 \pm 1.22$ \\
\hline 19 & $60.51 \pm 0.63$ & $67.39 \pm 2.17$ & $76.09 \pm 2.17$ & $54.13 \pm 1.59$ & $57.80 \pm 1.56$ & $74,31 \pm 1.59$ & $75.83 \pm 1.94$ & $81.46 \pm 1.12$ & $85.02 \pm 0,57$ \\
\hline $\mathrm{C}+$ & $100 \pm 0.0^{\mathrm{a}}$ & $100 \pm 0.0^{\mathrm{a}}$ & $100 \pm 0.0^{\mathrm{a}}$ & $100 \pm 0.0^{\mathrm{b}}$ & $100 \pm 0.0^{\mathrm{b}}$ & $100 \pm 0.0^{\mathrm{b}}$ & $100 \pm 0.0^{\mathrm{b}}$ & $100 \pm 0.0^{\mathrm{b}}$ & $100 \pm 0.0^{\mathrm{b}}$ \\
\hline $\mathrm{C}-$ & 0 & 0 & 0 & 0 & 0 & 0 & 0 & 0 & 0 \\
\hline
\end{tabular}

The percentage of mycelial growth inhibition is based on mycelium area measurements after $72 \mathrm{~h}$ of incubation. Each point represents the mean of three independent experiments. C+: positive control ( ${ }^{a}$ metalaxyl; ${ }^{\mathrm{b}}$ captan); $\mathrm{C}-$ : negative control (stock solution $1 \%$ ethanol/water).

group towards the iron, generating an interaction between Asn425 and this group. Compound 19, that showed the worst $\mathrm{IC}_{50}$ value and had a competitive mechanism, only oriented a hydroxyl group towards the metal.

It is known that flavonoids containing ortho-diOH groups have inhibitory activities against LOXs,${ }^{61,62}$ although it is not the main requirement. We show that there are differences in the type and potency of the inhibition between 11 and 18, so the presence of a catechol would not be an absolute structural requirement for this activity. Moreover, the most active compound (11) has three additional methoxy groups in the $3^{\prime}, 4^{\prime}, 5^{\prime}$ positions.

\section{DPPH radical scavenging activity}

The results obtained from the antioxidant activity assays are shown in Table 7. All the compounds were compared with Trolox. Compounds $\mathbf{1 1}$ and $\mathbf{1 8}$ showed more potent antioxidant activity than Trolox. The presence of the catechol group resulted in a significant increase of the antioxidant activity with respect to the compounds without this group. Hydroxy groups in meta positions (i.e., 19) and methoxy groups in meta and ortho positions of the A ring (i.e., 14 and 16) and methoxy groups in position 3 of the $B$ ring (i.e., 13 and 17) decrease the antioxidant activity. Hydroxy and methoxy groups on the $\mathrm{B}$ and $\mathrm{A}$ rings, respectively, increase the antioxidant activity.

\section{In vitro cytotoxic activity of $\mathbf{1 8}$}

One of the most effective synthesized chalcone as antioxidant and 5-hLOX inhibitory capacity was 18. Given that both biological activities are related to proliferation

Table 6. Results of 5-hLOX activity assays in presence of chalcones 11-19

\begin{tabular}{lcccc}
\hline Compound & Inhibition $^{\mathrm{a}} / \%$ & $\mathrm{IC}_{50} / \mu \mathrm{M}$ & $\mathrm{K}_{\mathrm{i}} / \mu \mathrm{M}$ & Type \\
\hline $\mathbf{1 6}$ & W.A & N.D & N.D & N.D \\
$\mathbf{1 7}$ & W.A & N.D & N.D & N.D \\
$\mathbf{1 8}$ & $88.36 \pm 2.18$ & $0.023 \pm 0.004$ & 1.962 & competitive \\
$\mathbf{1 9}$ & $58.60 \pm 5.42$ & $0.707 \pm 0.037$ & 0.006326 & competitive \\
$\mathbf{1 1}$ & $96.30 \pm 1.47$ & $0.011 \pm 0.004$ & N.D & mixed \\
$\mathbf{1 2}$ & W.A & N.D & N.D & N.D \\
$\mathbf{1 3}$ & W.A & N.D & N.D \\
$\mathbf{1 4}$ & $41.35 \pm 4.33$ & N.D & N.D & N.D \\
$\mathbf{1 5}$ & $11.67 \pm 13.13$ & N.D & N.D & N.D \\
NDGA & $93.42 \pm 5.87$ & N.D & N.D \\
\hline
\end{tabular}

${ }^{\mathrm{a}}$ Chalcone at $10 \mu \mathrm{M} ; \mathrm{IC}_{50}$ : half maximal inhibitory concentration; $\mathrm{K}_{\mathrm{i}}$ : inhibitory constant; W.A: without activity; N.D: not determined; NDGA: nordihydroguaiaretic acid. 


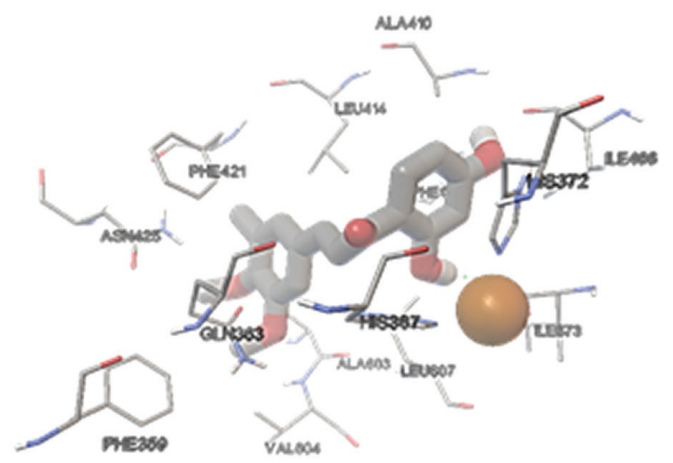

(a)

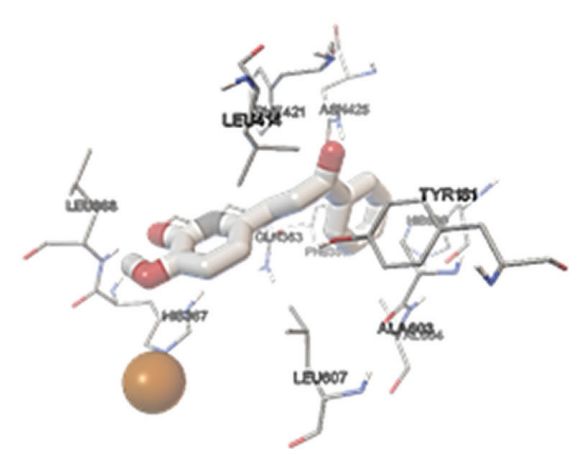

(b)

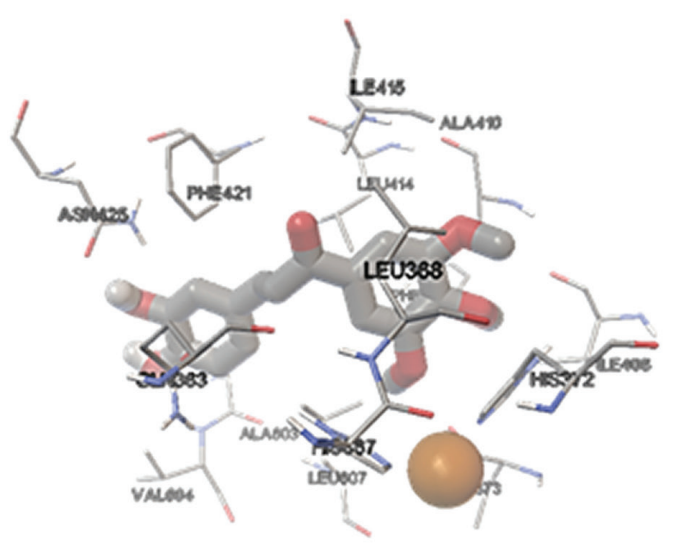

(c)

Figure 5. Docking results for chalcones with 5-hLOX. (a) 19, with a $\Delta \mathrm{G}_{\mathrm{b}}=-3.68 \mathrm{kcal} \mathrm{mol}^{-1}$ and an experimental $\mathrm{k}_{\mathrm{i}}=1.96 \mu \mathrm{M}$; (b) 18, with a $\Delta \mathrm{G}_{\mathrm{b}}=-4.9 \mathrm{kcal} \mathrm{mol}^{-1}$ and an experimental $\mathrm{k}_{\mathrm{i}}=0.016 \mu \mathrm{M}$; (c) 11, with a $\Delta \mathrm{G}_{\mathrm{b}}=-4.25 \mathrm{kcal} \mathrm{mol}^{-1}$ and an experimental $\mathrm{k}_{\mathrm{i}}=0.06 \mu \mathrm{M}$. The orange ball represents the iron atom, located in the active site.

and viability of cancer cells, we measured 18-induced cytotoxic activity against MDA-MB-231 (human breast adenocarcinoma cell line), B16-F10 (mouse melanoma cells) and MEF (primary mouse embryonic fibroblast). Our results in the Table 8 show that $\mathbf{1 8}$ exhibits a 4-fold higher selectivity upon B16-F10 compared to the effect on non-cancerous cells (MEF). 18 also exhibited
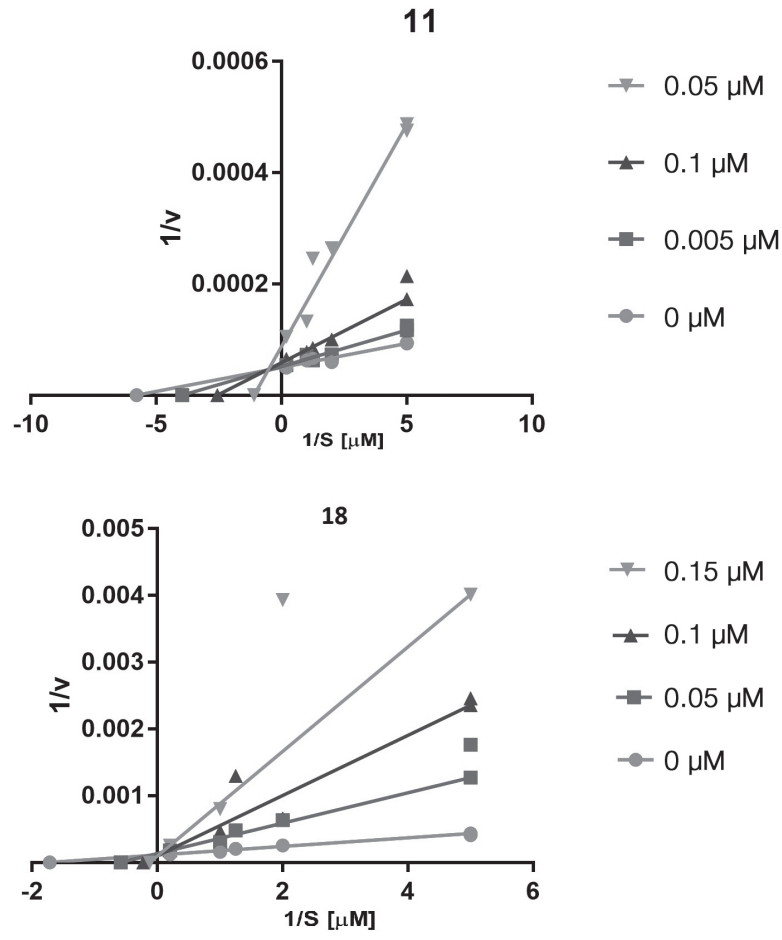

$$
\begin{aligned}
& -0.15 \mu \mathrm{M} \\
& -0.1 \mu \mathrm{M} \\
& -0.05 \mu \mathrm{M} \\
& -0 \mu \mathrm{M}
\end{aligned}
$$

19

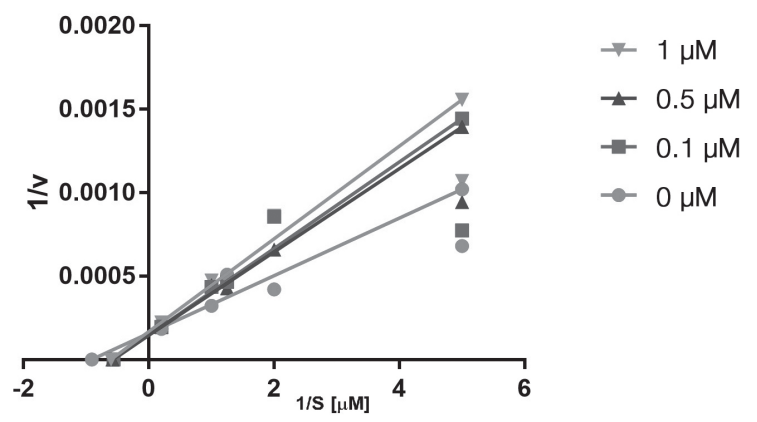

Figure 6. The Lineweaver-Burk plot of the inhibition of 5-hLOX by three chalcones (11, 18 and 19).

Table 7. Screening results of DPPH radical scavenging activity of chalcones 11-19

\begin{tabular}{lc}
\hline Compound & $\mathrm{IC}_{50} \pm \mathrm{SD} / \mu \mathrm{M}$ \\
\hline $\mathbf{1 1}$ & $11.75 \pm 0.21$ \\
$\mathbf{1 2}$ & $33.50 \pm 1.52$ \\
$\mathbf{1 3}$ & $49.04 \pm 1.25$ \\
$\mathbf{1 4}$ & $54.40 \pm 5.82$ \\
$\mathbf{1 5}$ & $\mathrm{NA}$ \\
$\mathbf{1 6}$ & $73.03 \pm 7.53$ \\
$\mathbf{1 7}$ & $104.26 \pm 5.44$ \\
$\mathbf{1 8}$ & $12.45 \pm 0.39$ \\
$\mathbf{1 9}$ & $\mathrm{NA}$ \\
Trolox & $22.54 \pm 0.61$ \\
\hline
\end{tabular}

Antioxidant activity is shown as $\mathrm{IC}_{50}$ (half maximal inhibitory concentration) values in $\mu \mathrm{M}$ concentrations. NA: no activity. All compounds were analyzed in triplicate and the results expressed as average \pm standard deviation $(\mathrm{SD})$. 
cytotoxic activity against MDA-MB-231, but with no selectivity over MEF. When the cytotoxic effect of $\mathbf{1 8}$ against B16-F10 was compared with commonly used chemotherapeutic drugs, it could be verified that $\mathbf{1 8}$ showed 29- and 8-fold lesser activity than taxol and etoposide, respectively. Furthermore, 18 exhibited 300and 50-fold lesser cytotoxic activity against MDA-MB231 cell line. It is noteworthy that $\mathbf{1 8}$ exhibited antioxidant activity and 5-LOX inhibition at lower concentrations than the needed to exert cytotoxic activity.

Table 8. Cytotoxic activities of $\mathbf{1 8}$ against cancer and non-cancerous cells

\begin{tabular}{lccc}
\hline \multirow{2}{*}{ Compound } & \multicolumn{3}{c}{$\mathrm{IC}_{50} \pm \mathrm{SD} / \mu \mathrm{M}$} \\
\cline { 2 - 4 } & $\mathrm{MDA}-\mathrm{MB}-231$ & $\mathrm{~B} 16-\mathrm{F} 10$ & $\mathrm{MEF}$ \\
\hline $\mathbf{1 8}$ & $67.58 \pm 5.76$ & $13.96 \pm 2.47$ & $60.66 \pm 4.42$ \\
Taxol & $0.21 \pm 0.05$ & $0.48 \pm 0.08$ & $0.40 \pm 0.07$ \\
Etoposide & $1.33 \pm 0.28$ & $1.74 \pm 0.32$ & $1.03 \pm 0.17$ \\
\hline
\end{tabular}

SD: standard deviation; MDA-MB-231: human breast adenocarcinoma cell line; B16-F10: mouse melanoma cells; MEF: primary mouse embryonic fibroblast.

\section{Conclusions}

Apparently a 3,4-diOH substitution on the chalcone skeleton plays a key role in the potentiation capacity of the $\beta$-lactam antibiotic methicillin. For this reason, the chalcone 18 was subjected to cytotoxicity studies reinforcing a possible use in the control of resistant pathogens in vivo. These studies showed a low cytotoxicity against MEF cell line. This clearly suggests that $\mathbf{1 8}$ could be useful for the treatment against resistant bacteria, although further studies are needed to confirm this possibility. Although chalcones with 3,4-O-di-hydroxy groups are sometimes considered interferers of all assays, ${ }^{63}$ it appears not to be applied here because the most active chalcones against phytopathogens and human pathogenic fungi $(\mathbf{1 2}, 15$ and 17) do not have this substitution pattern.

In both cases, bacteria and fungi, the sensitivity for each molecule can vary, not only by cellular structural characteristics such as wall and plasma membrane, but also by differences in their mechanisms of tolerance to stress and detoxification. ${ }^{64}$

Due to the versatility of biological properties showed here to this kind of compounds, simple and safe polyoxygenated chalcones not only have potential uses in different biological areas, whose specificity or action target depends largely on their functional groups, but also they would help us to fight resistant pathogens to commercial antibiotics through the specific re-sensitization.

\section{Experimental}

Chemistry

General data

All purchased chemical reagents (Merck or SigmaAldrich) were of the highest available purity and were used without previous purification. Melting points $\left(\mathrm{mp}\right.$ in ${ }^{\circ} \mathrm{C}$ ) were measured on a Stuart-Scientific SMP3 melting point apparatus (Stone, United Kingdom) and are uncorrected. Infrared (IR) spectra were recorded as a thin film (14 and 15) or in $\mathrm{KBr}$ disks $(11,12,13,16,17,18$ and 19) in a Thermo Scientific Nicolet 6700 FT-IR spectrometer (Massachusetts, USA), and wave numbers are reported in $\mathrm{cm}^{-1}$. Low resolution mass spectra (MS) were recorded on a Thermo Scientific, Trace GC Ultra, ISQ mass spectrometer (Austin, USA) at $70 \mathrm{eV}$ ionizing voltage and are given as $\mathrm{m} / \mathrm{z}$ (rel. int., in percentage). High-resolution mass spectra (HRMS) were recorded on an Exactive ${ }^{\mathrm{TM}}$ Plus Orbitrap spectrometer (Thermo Scientific, Bremen, Germany) by infusion, applying a voltage of $5 \mathrm{kV}$ in the positive ionization mode. The spectra were recorded using full scan mode, covering a mass range from $\mathrm{m} / \mathrm{z}, 140$ to 430 . The resolution was set to 140000, and maximum loading time for the ion cyclotron resonance (ICR) cell was set to $200 \mathrm{~ms} .{ }^{1} \mathrm{H}$ and ${ }^{13} \mathrm{C}$ nuclear magnetic resonance (NMR), 2D heteronuclear single quantum correlation (HSQC) and 2D heteronuclear multiple bond correlation (HMBC) spectra were recorded in $\mathrm{CDCl}_{3}$ or DMSO- $d_{6}$ solutions and referenced to the residual solvent peaks at $\delta 7.26$ and $2.50 \mathrm{ppm}$ for ${ }^{1} \mathrm{H}$ and $\delta 77.0$ and $39.5 \mathrm{ppm}$ for ${ }^{13} \mathrm{C}$, respectively, on a Bruker Avance 400 NMR spectrometer (Rheinstetten, Germany) operating at $400.1 \mathrm{MHz}$ for ${ }^{1} \mathrm{H}$ and $100.6 \mathrm{MHz}$ for ${ }^{13} \mathrm{C}$. Chemical shifts are reported as $\delta(\mathrm{ppm})$, and coupling constants $(J)$ are given in Hz. Silica gel (200-400 mesh, Merck, Darmstadt, Germany) was used for column chromatography and HF-254 silica gel plates for thin layer chromatography (TLC). TLC spots were detected both under a UV lamp and by heating after drenching in $10 \% \mathrm{H}_{2} \mathrm{SO}_{4}$ in $\mathrm{H}_{2} \mathrm{O}$. Antioxidant effects were determined in a Thermo Scientific Multiskan GO 96-well plate photometer (Vantaa, Finland).

\section{General experimental procedure}

\section{General procedure in alkaline condition}

To a solution of acetophenone ( $1 \mathrm{~mol}$ equiv.) and appropriate benzaldehyde ( $1 \mathrm{~mol}$ equiv.) in methanol ( $5 \mathrm{~mL}$ ), $\mathrm{KOH}$ (4 mol equiv.) was added in one portion. The mixture was warmed to $50{ }^{\circ} \mathrm{C}$ and stirred until completion of reaction (monitored by TLC). Then the solvent was removed under reduced pressure, poured into ice water and 
neutralized with aqueous $10 \% \mathrm{HCl}$ solution. The residue was extracted with ethyl acetate $(15 \mathrm{~mL} \times 3$ times). The combined organic layer was washed with brine, dried over anhydrous sodium sulfate and filtered; the solvent was evaporated under reduced pressure. The mixture was subjected to silica gel flash column chromatography (ethyl acetate/hexanes as the mobile phase) to yield the products. The fractions of the product were dried and recrystallized from ethanol to obtain pure chalcones.

\section{General procedure in acid condition}

To a stirred mixture of acetophenone (1 mol equiv.) and benzaldehyde ( 1 mol equiv) in absolute ethanol $(5 \mathrm{~mL})$, thionyl chloride $(0.5 \mathrm{~mL}, 3 \mathrm{~mol}$ equiv.) was added dropwise and the reaction was monitored by TLC. After standing for $16 \mathrm{~h}$, ice water (30 g approximately) was added to the reaction mixture in order to decompose the excess of $\mathrm{SOCl}_{2}$. Then, ethyl acetate $(30 \mathrm{~mL})$ was added and the organic layer was separated, and a new extraction with ethyl acetate was performed. The pooled organic solutions were dried over anhydrous sodium sulfate and filtered; the solvent was evaporated under reduced pressure. The mixture was subjected to silica gel flash column chromatography (ethyl acetate/hexanes as the mobile phase) to yield the products. Solid chalcones were recrystallized from ethanol.

All structures were confirmed by IR and NMR spectra as discussed below.

\section{Physical data of chalcones}

1-(3,4,5-Trimethoxyphenyl)-3-(3,4-dihydroxyphenyl)-prop2-en-1-one (11)

It was obtained from 1-(3',4',5'-trimethoxyphenyl) ethanone (1, $0.5 \mathrm{~g}, 2.4 \mathrm{mmol})$ and 3,4-dihydroxybenzaldehyde $(7,0.327 \mathrm{~g}, 2.4 \mathrm{mmol})$ in $5 \mathrm{~mL}$ of ethanol and $0.5 \mathrm{~mL}$ of $\mathrm{SOCl}_{2}(0.82 \mathrm{~g}, 6.9 \mathrm{mmol})$, stirring for $16 \mathrm{~h}$ as described above. mp 151-153 ${ }^{\circ} \mathrm{C}$ (lit. ${ }^{65} 158-159{ }^{\circ} \mathrm{C}$ ); IR (KBr) $v / \mathrm{cm}^{-1} 3331$, 2942, 1645, 1586, 1558; HRMS $\mathrm{m} / 2$, observed: 331.1178; $\mathrm{C}_{18} \mathrm{H}_{19} \mathrm{O}_{6}[\mathrm{M}+\mathrm{H}]^{+}$requires: $331.1182 ;{ }^{1} \mathrm{H} \mathrm{NMR}(400 \mathrm{MHz}$, $\left.\mathrm{CDCl}_{3}\right) \delta 7.75(\mathrm{~d}, 1 \mathrm{H}, J 15.5 \mathrm{~Hz}, 2-\mathrm{CH}=3-\mathrm{CH}), 7.32(\mathrm{~d}$, $1 \mathrm{H}, J 15.5 \mathrm{~Hz}, 2-\mathrm{CH}=3-\mathrm{CH}$ ), 7.27 (s, $1 \mathrm{H}, 3-\mathrm{ArH}-2$ ), 7.25 (s, 2H, 1-ArH-2,6), 7.14 (dd, $1 \mathrm{H}, J$ 8.2, $1.8 \mathrm{~Hz}, 3-\mathrm{Ar} H-6$ ), $6.94(\mathrm{~d}, 1 \mathrm{H}, J 8.2 \mathrm{~Hz}, 3-\mathrm{ArH}-5), 6.81$ (s, 1H, ArOH-3), 6.59 (s, $1 \mathrm{H}, \mathrm{ArOH}-4), 3.96$ (s, 3H, 1- $\left.\mathrm{ArOCH}_{3}-4\right), 3.94$ (s, $\left.6 \mathrm{H}, 1-\mathrm{ArOCH}_{3}-3,5\right) ;{ }^{13} \mathrm{C}$ NMR (100 MHz, $\left.\mathrm{CDCl}_{3}\right) \delta 56.4$ (1- $\left.\mathrm{ArOCH}_{3}-3,5\right), 61.0\left(1-\mathrm{ArOCH}_{3}-4\right), 106.1$ (1-ArCH-2,6), 115.0 (3-ArC-2), 115.6 (3-ArCH-5), $119.3(2-\mathrm{CH}=3-\mathrm{CH})$, 122.8 (3-ArCH-6), 127.7 (3-ArC-1), 133.5 (1-ArC-1), 142.5 (1-ArC-4), 144.2 (3-ArC-3), 145.9 (2-CH=3-CH), 147.1 (3-ArC-4), $153.1(1-\operatorname{ArC}-3,5), 190.3(1-C=\mathrm{O})$.
1-(2,5-Dimethoxyphenyl)-3-(4-hydroxy-3-methoxyphenyl)prop-2-en-1-one (12)

It was obtained from 1-(2,5-dimethoxyphenyl) ethanone $(2,0.5 \mathrm{~g}, 2.78 \mathrm{mmol})$ and 4-hydroxy3-methoxybenzaldehyde (8, $0.426 \mathrm{~g}, 2.8 \mathrm{mmol})$ in $10 \mathrm{~mL}$ of methanol and $\mathrm{KOH}(0.83 \mathrm{~g}, 14.8 \mathrm{mmol})$, stirring for $2 \mathrm{~h}$ as described above. mp 96-98 ${ }^{\circ} \mathrm{C}$; IR $(\mathrm{KBr}) \mathrm{v} / \mathrm{cm}^{-1}$ 3391, 3067, 3002, 2941, 2836, 1650, 1577, 1513; MS m/z (\%): 314 (100), 299 (25), 283 (19), 177 (95), 137 (83); HRMS $m / z$, observed: $315.1227 ; \mathrm{C}_{18} \mathrm{H}_{19} \mathrm{O}_{5}[\mathrm{M}+\mathrm{H}]^{+}$ requires: $315.1232 ;{ }^{1} \mathrm{H}$ NMR (400 $\left.\mathrm{MHz}, \mathrm{CDCl}_{3}\right) \delta 7.55$ (d, $1 \mathrm{H}, J 15.8 \mathrm{~Hz}, 2-\mathrm{CH}=3-\mathrm{CH}), 7.24$ (d, 1H, $J 15.8 \mathrm{~Hz}$, 2-CH=3-CH), 7.18-7.16 (m, 2H, 1-ArH-6', 3-ArH-6), 7.10 (d, 1H, J 1.6 Hz, 3-ArH-2), 7.04 (dd, 1H, J 8.9, 3.1 Hz, 1-ArH-4), 6.97-6.94 (m, 2H, 1-ArH-3, 3-ArH-5), 5.96 (s, $1 \mathrm{H}, 3-\mathrm{ArOH}-4), 3.95$ (s, 3H, $\mathrm{ArOCH}_{3}$ ), 3.87 (s, 3H, $\left.\mathrm{ArOCH}_{3}\right), 3.83\left(\mathrm{~s}, 3 \mathrm{H}, \mathrm{ArOCH}_{3}\right) ;{ }^{13} \mathrm{C}$ NMR $(100 \mathrm{MHz}$, $\left.\mathrm{CDCl}_{3}\right) \delta 55.8\left(\mathrm{ArOCH}_{3}\right), 55.9\left(\mathrm{ArOCH}_{3}\right), 56.6\left(\mathrm{ArOCH}_{3}\right)$, 110.0 (3-ArCH-2), 113.4 (1-ArCH-3'), 114.4 (3-ArCH-6), 114.8 (3-ArCH-5), 118.6 (1-ArCH-4), 123.2 (1-ArCH-6), $124.7(2-\mathrm{CH}=3-\mathrm{CH}), 127.6(1-\mathrm{ArC}-1), 130.0(3-\mathrm{ArC}-1)$, $144.1(2-\mathrm{CH}=3-\mathrm{CH}), 146.7$ (3-ArC-3), 148.1 (3-ArC-4), 152.3 (1-ArC-2), 153.6 (1-ArC-5), 192.8 (1-C=O).

1-(3,4,5-Trimethoxyphenyl)-3-(4-hydroxy-3-methoxyphenyl)-prop-2-en-1-one (13)

It was obtained from 1-(3',4',5'-trimethoxyphenyl) ethanone (1, $0.5 \mathrm{~g}, 2.4 \mathrm{mmol})$ and 4-hydroxy3-methoxybenzaldehyde $(\mathbf{8}, 0.361 \mathrm{~g}, 2.4 \mathrm{mmol})$ in $5 \mathrm{~mL}$ of ethanol and $0.5 \mathrm{~mL}$ of $\mathrm{SOCl}_{2}(0.82 \mathrm{~g}, 6.9 \mathrm{mmol})$, stirring for $16 \mathrm{~h}$ as described above. $\mathrm{mp} 88-91^{\circ} \mathrm{C}$ (lit. ${ }^{45} 75-76^{\circ} \mathrm{C}$ ); IR (KBr) v / cm ${ }^{-1}$ 3512, 3429, 3086, 2994, 2963, 2941, 2839, 1647, 1586, 1561, 1516; MS m/z (\%): 344 (100), 329 (65), 313 (29), 145 (28); ${ }^{1} \mathrm{H}$ NMR (400 MHz, $\mathrm{CDCl}_{3}$ ) $\delta 7.75$ $(\mathrm{d}, 1 \mathrm{H}, J 15.6 \mathrm{~Hz}, 2-\mathrm{CH}=3-\mathrm{CH}), 7.32(\mathrm{~d}, 1 \mathrm{H}, J 15.6 \mathrm{~Hz}$, $2-\mathrm{CH}=3-\mathrm{CH}), 7.30$ (s, 2H, 1-ArH-2,6), $7.25(\mathrm{dd}, 1 \mathrm{H}$, $J$ 9.6, $1.5 \mathrm{~Hz}, 3-\mathrm{Ar} H-6), 7.12$ (d, $1 \mathrm{H}, J 1.5 \mathrm{~Hz}, 3-\mathrm{Ar} H-2$ ), 6.97 (d, 1H, $J 8.2 \mathrm{~Hz}, 3-\mathrm{ArH}-5$ ), 5.97 (s, 1H, 3-Ar-OH-4), 3.96 (s, 3H, 3- $\left.\mathrm{ArOCH}_{3}-3\right), 3.95$ (s, 6H, 1- $\left.\mathrm{ArOCH}_{3}-3,5\right)$, 3.94 (s, 3H, 1-ArOCH$\left.H_{3}-4\right) ;{ }^{13} \mathrm{C}$ NMR $\left(100 \mathrm{MHz}, \mathrm{CDCl}_{3}\right)$ $\delta 56.0\left(\mathrm{ArOCH}_{3}\right), 56.4\left(1-\mathrm{ArOCH}_{3}-3,5\right), 61.0\left(\mathrm{ArOCH}_{3}\right)$, 106.1 (1-ArCH-2,6), 110.4 (3-ArCH-2), 114.9 (3-ArCH-5), $119.6(2-\mathrm{CH}=3-\mathrm{CH}), 123.0$ (3-ArCH-6), 127.5 (3-ArC-1), 133.8 (1-ArC-1), 142.3 (1-ArC-4), $145.2(2-\mathrm{CH}=3-\mathrm{CH})$, 146.8 (3-ArC-3), 148.3 (3-ArC-4), 153.1 (1-ArC-3,5), $189.5(1-C=\mathrm{O})$.

1-(2,4-Dimethoxyphenyl)-3-(4-hydroxy-3-methoxyphenyl)prop-2-en-1-one (14)

It was obtained from 1-(2,4-dimethoxyphenyl)ethanone $(3,1.0 \mathrm{~g}, 5.6 \mathrm{mmol})$ and 4-hydroxy-3-methoxybenzaldehyde 
$(8,0.93 \mathrm{~g}, 6.1 \mathrm{mmol})$ in $5 \mathrm{~mL}$ of ethanol and $0.81 \mathrm{~mL}$ of $\mathrm{SOCl}_{2}(1.33 \mathrm{~g}, 11.1 \mathrm{mmol})$, stirring for $1 \mathrm{~h}$ as described above. Pale yellow oil (lit. ${ }^{66}$ sticky-solid); IR (film) $\mathrm{v} / \mathrm{cm}^{-1}$ 3370, 2940, 2840, 1648, 1601, 1512; MS m/z (\%): 314 (100), 299 (49), 178 (90), 165 (98), 137 (70); ${ }^{1} \mathrm{H}$ NMR $\left(400 \mathrm{MHz}, \mathrm{CDCl}_{3}\right) \delta 7.71(\mathrm{~d}, 1 \mathrm{H}, J 8.7 \mathrm{~Hz}, 1-\mathrm{ArH}-6), 7.60$ $(\mathrm{d}, 1 \mathrm{H}, J 15.7 \mathrm{~Hz}, 2-\mathrm{CH}=3-\mathrm{CH}), 7.33(\mathrm{~d}, 1 \mathrm{H}, J 15.7 \mathrm{~Hz}$, 2-CH=3-CH), 7.15 (dd, $1 \mathrm{H}, J$ 8.2, $1.6 \mathrm{~Hz}, 3-\mathrm{ArH}-6)$, $7.06(\mathrm{~d}, 1 \mathrm{H}, J 1.6 \mathrm{~Hz}, 3-\mathrm{Ar} H-2), 6.92(\mathrm{~d}, 1 \mathrm{H}, J 8.2 \mathrm{~Hz}$, 3-ArH-5), 6.54 (dd, 1H, J 8.6, 2.1 Hz, 1-ArH-5), 6.48 (d, $1 \mathrm{H}, J 2.1 \mathrm{~Hz}, 1-\mathrm{Ar} H-3$ ), 6.22 (s, $1 \mathrm{H}, 3-\mathrm{ArOH}-4$ ), 3.90 (s, $\left.3 \mathrm{H}, 3-\mathrm{ArOCH}_{3}-3\right), 3.88$ (s, 3H, 1- $\left.\mathrm{ArOCH}_{3}\right), 3.85$ (s, 3H, 1- $\left.\mathrm{ArOCH}_{3}\right) ;{ }^{13} \mathrm{C} \mathrm{NMR}\left(100 \mathrm{MHz}, \mathrm{CDCl}_{3}\right) \delta 55.5\left(\mathrm{ArOCH}_{3}\right)$, $55.7\left(\mathrm{ArOCH}_{3}\right), 55.8\left(\mathrm{ArOCH}_{3}\right), 98.6(1-\mathrm{ArCH}-3), 105.0$ (1-ArCH-5), 110.2 (3-ArCH-2), 114.8 (3-ArCH-5), 122.2 (1-ArC-1), 122.7 (3-ArCH-6), $124.8(2-\mathrm{CH}=3-\mathrm{CH}), 127.8$ (3-ArC-1), $132.6(1-\mathrm{ArCH}-6), 142.8(2-\mathrm{CH}=3-\mathrm{CH}), 146.7$ (3-ArC-3), 147.8 (3-ArC-4), 160.1 (1-ArC-OCH $\left.{ }_{3}\right), 163.9$ $\left(1-\mathrm{Ar} C-\mathrm{OCH}_{3}\right), 190.9(1-\mathrm{C}=\mathrm{O})$.

1-(2,5-Dimethoxyphenyl)-3-phenyl-prop-2-en-1-one (15)

It was obtained from 1-(2',5'-dimethoxyphenyl) ethanone $(\mathbf{2}, 2.0 \mathrm{~g}, 11.1 \mathrm{mmol})$ and benzaldehyde $(\mathbf{9}$, $1.3 \mathrm{~g}, 12.2 \mathrm{mmol})$ in $10 \mathrm{~mL}$ of methanol and $\mathrm{KOH}(2.5 \mathrm{~g}$, $44.4 \mathrm{mmol}$ ), stirring for $2 \mathrm{~h}$ as described above. Yellow oil (lit. ${ }^{67}$ yellow oil); IR (film) $\mathrm{v} / \mathrm{cm}^{-1} 3060,3001,2942,2911$, 2835, 1658, 1594, 1575; MS m/z (\%): 268 (100), 253 (15), 237 (25), 177 (60), 165 (70), 151 (61), 103 (65); ${ }^{1} \mathrm{H}$ NMR $\left(400 \mathrm{MHz}, \mathrm{CDCl}_{3}\right) \delta 7.65$ (d, $\left.1 \mathrm{H}, J 15.8 \mathrm{~Hz}, 2-\mathrm{CH}=3-\mathrm{CH}\right)$, 7.61-7.59 (m, 2H, 3-ArH-2,6), 7.42 (d, 1H, J $15.8 \mathrm{~Hz}$, 2-CH=3-CH), 7.40-7.38 (m, 3H, 3-ArH-3,4,5), 7.19 (d, 1H, $J 3.1 \mathrm{~Hz}, 1-\mathrm{ArH}-6), 7.03$ (dd, 1H, J 9.0, $3.1 \mathrm{~Hz}, 1-\mathrm{ArH}-4)$, 6.94 (d, 1H, J 9.0 Hz, 1-ArH-3), 3.86 (s, 3H, $\mathrm{ArOCH}_{3}$ ), $3.81\left(\mathrm{~s}, 3 \mathrm{H}, \mathrm{ArOCH}_{3}\right) ;{ }^{13} \mathrm{C} \mathrm{NMR}\left(100 \mathrm{MHz}, \mathrm{CDCl}_{3}\right) \delta 55.8$ $\left(\mathrm{ArOCH}_{3}\right), 56.5\left(\mathrm{ArOCH}_{3}\right), 113.4(1-\mathrm{ArCH}-6), 114.4$ (1-ArC-3), 119.2 (2- $\mathrm{CH}=3-\mathrm{CH}), 126.9$ (1-ArCH-4), 128.4 (3-ArCH-2,6), 128.8 (3-ArCH-3,4,5), 129.6 (3-ArC-1), $130.2\left(1-\mathrm{ArC}-\mathrm{OCH}_{3}\right), 135.1\left(1-\mathrm{ArC}-\mathrm{OCH}_{3}\right), 143.2$ $(2-\mathrm{CH}=3-\mathrm{CH}), 152.6$ (1-ArC-2), 153.6 (1-ArC-5), 192.4 $(1-C=\mathrm{O})$.

1-(3,4-Dimethoxyphenyl)-3-(4-hydroxy-3-methoxyphenyl)prop-2-en-1-one (16)

It was obtained from 1-(3',4'-dimethoxyphenyl) ethanone $(4,0.5 \mathrm{~g}, 2.8 \mathrm{mmol})$ and 4-hydroxy3-methoxybenzaldehyde $(\mathbf{8}, 0.42 \mathrm{~g}, 2.8 \mathrm{mmol})$ in $5 \mathrm{~mL}$ of ethanol and $0.41 \mathrm{~mL}$ of $\mathrm{SOCl}_{2}(0.67 \mathrm{~g}, 5.6 \mathrm{mmol})$, stirring for $2 \mathrm{~h}$ as described above. mp $127-128^{\circ} \mathrm{C}\left(\right.$ lit $^{68}{ }^{12}$ 128-129 $\left.{ }^{\circ} \mathrm{C}\right)$; IR (KBr) v / $\mathrm{cm}^{-1} 3341,3078,2992,2930,2835,1643$, 1585, 1557, 1510, 1438, 1418, 1267; MS m/z (\%): 314 (100), 283 (65), 207 (90), 165 (58), 145 (39); ' $\mathrm{H}$ NMR
(400 MHz, $\left.\mathrm{CDCl}_{3}\right) \delta 7.73(\mathrm{~d}, 1 \mathrm{H}, J 15.5 \mathrm{~Hz}, 2-\mathrm{CH}=3-\mathrm{CH})$, $7.68(\mathrm{dd}, 1 \mathrm{H}, J$ 8.4, $1.8 \mathrm{~Hz}, 1-\operatorname{ArH}-6), 7.62(\mathrm{~d}, 1 \mathrm{H}$, $J 1.7 \mathrm{~Hz}, 3-\mathrm{Ar} H-6), 7.40$ (d, $1 \mathrm{H}, J 15.5 \mathrm{~Hz}, 2-\mathrm{CH}=3-\mathrm{CH}$ ), $7.23(\mathrm{dd}, 1 \mathrm{H}, J 8.2,1.6 \mathrm{~Hz}, 3-\mathrm{ArH}-6), 7.12(\mathrm{~d}, 1 \mathrm{H}, J 1.5 \mathrm{~Hz}$, 3-ArH-2), 6.95-6.92 (m, 2H, 1-ArH-5, 3-ArH-5), 5.95 (s, 1H, 3-ArOH-4), 3.97 (m, 9H, $\left.\mathrm{ArOCH}_{3}\right) ;{ }^{13} \mathrm{C}$ NMR $\left(100 \mathrm{MHz}, \mathrm{CDCl}_{3}\right) \delta$ 56.0-56.1 $\left(\mathrm{ArOCH}_{3}\right), 109.9$ (1-ArCH-5), 110.2 (3-ArCH-2), 110.8 (1-ArCH-2), 114.8 (3-ArCH-5), 119.4 (2- $\mathrm{CH}=3-\mathrm{CH}), 122.8$ (1-ArC-6), 123.0 (3-ArC-6), 127.6 (1-ArC-1), 131.5 (3-ArC-1), 144.3 $(2-\mathrm{CH}=3-\mathrm{CH}), 146.8$ (3-ArC-4), 148.1 (3-ArC-3), 149.2 (1-ArC-3), 153.1 (1-ArC-4), $188.7(1-C=\mathrm{O})$.

1-Phenyl-3-(4-hydroxy-3-methoxyphenyl)-prop-2-en-1-one (17)

It was obtained from acetophenone $(\mathbf{5}, 0.48 \mathrm{~g}, 4 \mathrm{mmol})$ and 4-hydroxy-3-methoxybenzaldehyde $(\mathbf{8}, 0.502 \mathrm{~g}$, $3.3 \mathrm{mmol})$ in $8 \mathrm{~mL}$ of ethanol and $0.24 \mathrm{~mL}$ of $\mathrm{SOCl}_{2}(0.39 \mathrm{~g}$, $3.3 \mathrm{mmol}$ ), stirring for $6 \mathrm{~h}$ as described above. $\mathrm{mp} 91-92^{\circ} \mathrm{C}$ (lit..$\left.^{69} 93{ }^{\circ} \mathrm{C}\right)$; IR (KBr) v / $\mathrm{cm}^{-1} 3322,3001,2938,2835$, $1655,1583,1564,1525,1454,1420,1369,1248 ; \mathrm{MS} \mathrm{m} / \mathrm{z}$ (\%): 254 (100), 237 (22), 223 (20), 165 (35), 145 (48), 124 (60); ${ }^{1} \mathrm{H}$ NMR $\left(400 \mathrm{MHz}, \mathrm{CDCl}_{3}\right) \delta 8.01(\mathrm{~d}, 2 \mathrm{H}, J 7.3 \mathrm{~Hz}$, 1-ArH-2,6), 7.75 (d, $1 \mathrm{H}, J 15.6 \mathrm{~Hz}, 2-\mathrm{CH}=3-\mathrm{CH}), 7.60-7.56$ (m, 1H, 1-ArCH-4), 7.52-7.48 (m, 2H, 1-ArH-3,5), 7.38 $(\mathrm{d}, 1 \mathrm{H}, J 15.6 \mathrm{~Hz}, 2-\mathrm{CH}=3-\mathrm{CH}), 7.22(\mathrm{dd}, 1 \mathrm{H}, J$ 8.2, $1.4 \mathrm{~Hz}, 3-\mathrm{ArH}-6$ ), 7.13 (d, 1H, J 1.4 Hz, 3-ArH-2), 6.96 (d, 1H, J 8.2 Hz, 3-ArH-5), 5.97 (s, 1H, 3-ArOH-4), 3.96 (s, 3H, 3- $\left.\left.\mathrm{ArOCH}_{3}-3\right) ;{ }^{13} \mathrm{C} \mathrm{NMR} \mathrm{(100} \mathrm{MHz,} \mathrm{CDCl}_{3}\right) \delta 56.0$ (3- $\mathrm{ArOCH}_{3}-3$ ), 110.0 (3-ArCH-2), 114.9 (3-ArCH-5), 119.8 (2- $\mathrm{CH}=3-\mathrm{CH}), 123.4$ (3-ArCH-6), 127.5 (3-ArC-1), 128.4 (1-ArCH-3,5), 128.6 (1-ArCH-2,6), 132.6 (1-ArCH-4), 138.5 (1-ArC-1), $145.2(2-\mathrm{CH}=3-\mathrm{CH}), 146.8$ (3-ArC-3), 148.3 (3-ArC-4), $190.7(1-C=\mathrm{O})$.

\section{1-Phenyl-3-(3,4-dihydroxyphenyl)-prop-2-en-1-one (18)}

It was obtained from acetophenone $(5,0.5 \mathrm{~g}, 4.2 \mathrm{mmol})$ and 3,4-dihydroxybenzaldehyde (7, $0.58 \mathrm{~g}, 4.2 \mathrm{mmol})$ in $5 \mathrm{~mL}$ of ethanol and $0.31 \mathrm{~mL}$ of $\mathrm{SOCl}_{2}(0.5 \mathrm{~g}, 4.2 \mathrm{mmol})$, stirring for $16 \mathrm{~h}$ as described above. mp $198-200{ }^{\circ} \mathrm{C} \mathrm{dec}$. (lit. $\left.{ }^{70} 200-201{ }^{\circ} \mathrm{C}\right)$; IR (KBr) v / $\mathrm{cm}^{-1} 3482,3304,1647$, 1582, 1563, 1441, 1365, 1365, 1284; MS m/z (\%): 240 (100), 223 (25), 163 (14), 110 (21), 77 (23); HRMS $\mathrm{m} / \mathrm{z}$, observed: $241.0861 ; \mathrm{C}_{15} \mathrm{H}_{13} \mathrm{O}_{3}[\mathrm{M}+\mathrm{H}]^{+}$requires: $241.0865 ;{ }^{1} \mathrm{H}$ NMR $\left(400 \mathrm{MHz}, \mathrm{DMSO}-d_{6}\right) \delta 9.42(\mathrm{br}$ s, 2H, 3-ArOH-3,4), 8.09 (d, 2H, J 7.5 Hz, 1-ArH-3,5), 7.65-7.62 (m, 1H, 1-ArH-4), 7.60 (s, 2H, 2-CH=3-CH), 7.56-7.52 (m, 2H, 1-ArH-2,6), 7.25 (s, 1H, 3-ArH-2), 7.18 (d, $1 \mathrm{H}, J 8.1 \mathrm{~Hz}, 3-\mathrm{ArH}-6), 6.80$ (d, $1 \mathrm{H}, J 8.1 \mathrm{~Hz}, 3-\mathrm{ArH}-5$ ); ${ }^{13} \mathrm{C}$ NMR $\left(100 \mathrm{MHz}\right.$, DMSO- $\left.d_{6}\right) \delta 115.5$ (3-ArCH-2), 115.7 (3-ArCH-5), 118.4 (2- $\mathrm{CH}=3-\mathrm{CH}), 122.2$ (3-ArCH-6), 126.2 
(3-ArC-1), 128.3 (1-ArCH-3,5), 128.7 (1-ArCH-2,6), 132.7

(1-ArCH-4), $138.0(1-\mathrm{ArC}-1), 145.0(2-\mathrm{CH}=3-\mathrm{CH}), 145.6$

(3-ArC-3), 148.8 (3-ArC-4), $189.0(1-C=\mathrm{O})$.

1-(2,4-Dihydroxyphenyl)-3-(3,4,5-trimethoxyphenyl)-prop-

2-en-1-one (19)

It was obtained from 1-(2',4'-dimethoxyphenyl)ethanone $(3,0.5 \mathrm{~g}, 3.3 \mathrm{mmol})$ and 3,4,5-trimethoxybenzaldehyde $(\mathbf{1 0}, 0.65 \mathrm{~g}, 3.3 \mathrm{mmol})$ in $6 \mathrm{~mL}$ of methanol and $\mathrm{KOH}$ ( $2 \mathrm{~g}, 35.6 \mathrm{mmol}$ ), stirring for $2 \mathrm{~h}$ as described above. mp 181-183 ${ }^{\circ} \mathrm{C}$ (lit. $\left.{ }^{71} 188-190{ }^{\circ} \mathrm{C}\right)$; IR (KBr) v / $\mathrm{cm}^{-1}$ 3329, 3016, 2978, 2943, 2833, 1623, 1583, 1506, 1434, 1375, 1333, 1303; MS m/z (\%): 330 (48), 194 (37), 181 (100); ${ }^{1} \mathrm{H}$ NMR (400 MHz, DMSO- $\left.d_{6}\right) \delta 13.51(\mathrm{~s}, 1 \mathrm{H}$, 1-ArOH-2), 10.75 (s, 1H, 1-ArOH-4), 8.23 (d, $1 \mathrm{H}, J 9.0 \mathrm{~Hz}$, 1-ArH-6), 7.91 (d, $1 \mathrm{H}, J 15.4 \mathrm{~Hz}, 2-\mathrm{CH}=3-\mathrm{CH}), 7.75$ (d, $1 \mathrm{H}, J 15.3 \mathrm{~Hz}, 2-\mathrm{CH}=3-\mathrm{CH}$ ), 7.23 (s, 2H, 3-ArCH-2,6), $6.44(\mathrm{dd}, 1 \mathrm{H}, J 8.8,2.3 \mathrm{~Hz}, 1-\operatorname{ArH}-5), 6.29(\mathrm{~d}, 1 \mathrm{H}$, $J 2.3 \mathrm{~Hz}, 1-\mathrm{ArH}-3$ ), 3.86 (s, 6H, 3- $\mathrm{ArOCH}_{3}-3,5$ ), 3.71 (s, $\left.3 \mathrm{H}, 3-\mathrm{ArOCH}_{3}-4\right) ;{ }^{13} \mathrm{C}$ NMR (100 MHz, DMSO- $\left.d_{6}\right) \delta 56.1$ (3- $\left.\mathrm{ArOCH}_{3}-3,5\right)$, 60.1 (3- $\left.\mathrm{ArOCH}_{3}-4\right), 102.6$ (1- $\mathrm{ArCH}-3$ ), 106.7 (3-ArCH-2,6), 108.2 (1-ArCH-5), 113.0 (1-ArC-1), $120.2(2-\mathrm{CH}=3-\mathrm{CH}), 130.1$ (3-ArC-1), 133.2 (1-ArCH-6), 139.8 (3-ArC-4), $144.2(2-\mathrm{CH}=3-\mathrm{CH}), 153.1$ (3- $\mathrm{ArC}-3,5)$, 165.2 (1-ArC-4), 165.9 (1-ArC-2), 191.5 (1-C=O).

\section{Cytotoxicity assays}

In vitro antibacterial activity assays, human pathogens

\section{Minimum inhibitory concentration assay}

Two clinical isolates of methicillin resistant $S$. Aureus (622-4 and 97-7), and one clinical isolate of E. coli 33.1, kindly donated by Dr Marcela Wilkens from Universidad de Santiago de Chile (Chile) were used, and as control strains S. aureus (NCTC8325-4) and E. coli (ATCC25922) were used. The antimicrobial activities of chalcones against strains E. coli (ATCC25922), E. coli multi-resistant (33.1), S. aureus (NCTC8325-4) and methicillin-resistant $S$. aureus 97-7, were determined using the microdilution method established by CLSI. ${ }^{72}$ Briefly, stock solutions $\left(5 \mathrm{mg} \mathrm{mL}^{-1}\right)$ of compounds in DMSO were diluted in Mueller-Hinton broth (MHB) to the different two-fold assay concentrations. The final concentration of DMSO was $\leq 2.5 \%$ and does not affect the microbial growth. The obtained solution was then added to MHB, and serially two-fold diluted (in a 96-well microplate). $100 \mu \mathrm{L}$ of inoculum $1.5 \times 10^{6}$ colony forming unit (CFU) $\mathrm{mL}^{-1}$, prepared in MHB, was then added. The plates were sealed with a tight-fitting plastic cover, then incubated at $37^{\circ} \mathrm{C}$ for $18 \mathrm{~h}$. The assay was repeated three times. Wells containing MHB, $100 \mu \mathrm{L}$ of inoculum and
DMSO (final concentration of $\leq 2.5 \%$ ) served as negative controls. The MIC was defined as the lowest concentration of compounds resulting in the complete inhibition of visible growth.

\section{Checkerboard dilution test}

The type of interaction of the combination of chalcones 11 and 18 with methicillin was investigated with the checkerboard method. ${ }^{73}$ Briefly, the uppermost row (A) of a 96-well microtiter plate contained substance $\mathrm{X}$ in a concentration of about four times the expected MIC of the microorganism examined. Each following row (B-H) contained half the concentration of the previous one. The same procedure was carried out along the columns (1-12) with substance Y. So, each well contained a unique combination of the two substances (X and $\mathrm{Y}$ ). At last $100 \mu \mathrm{L}$ of Mueller-Hinton broth containing about

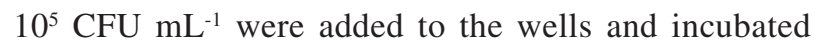
at $37{ }^{\circ} \mathrm{C}$ for $24 \mathrm{~h}$. The concentrations of the first wells without visible growth along the stepwise boundary between inhibition and growth were used to calculate the fractional inhibitory concentration index (FICI) as follows: $\mathrm{FICI}=$ fractional inhibitory concentration of $\mathrm{A}\left(\mathrm{FIC}_{\mathrm{A}}\right)+$ fractional inhibitory concentration of $\mathrm{B}\left(\mathrm{FIC}_{\mathrm{B}}\right)=(\mathrm{MIC}$ of drug A in combination / MIC of drug A alone) + (MIC of drug B in combination / MIC of drug B alone). FICI was interpreted as follows: synergy, $<0.5$; partial synergy, 0.5-0.75; additive effect, 0.76-1.0; indifference, 1.0-4.0; and antagonism, $>4.0 .^{74}$

In vitro antifungal activity assays against human pathogens

\section{Microorganisms and media}

For the antifungal evaluation, standardized strains from the American Type Culture Collection (ATCC, Rockville, MD, USA), C. albicans ATCC 10231 and C. neoformans ATCC 32264, were used. Strains were grown on Sabouraud-chloramphenicol agar slants for $48 \mathrm{~h}$ at $30^{\circ} \mathrm{C}$ and sub-cultured every 15 days to prevent pleomorphic transformations. Inocula were obtained according to reported procedures ${ }^{59}$ and adjusted to $1-5 \times 10^{3} \mathrm{CFU} \mathrm{mL}^{-1}$.

\section{Fungal growth inhibition}

The fungal growth inhibition percentage was determined with broth microdilution techniques performed in 96-well microplates according to the CLSI reference method for broth dilution antifungal susceptibility testing of yeasts, approved standard M27-A3. ${ }^{59}$ For the assay, compoundtest wells (CTWs) were prepared with stock solutions of each compound in DMSO (maximum concentration 1\%), diluted with Roswell Park Memorial Institute (RPMI)-1640 
medium, to final concentrations range $250-3.9 \mu \mathrm{g} \mathrm{mL} \mathrm{m}^{-1}$. An inoculum suspension $(100 \mu \mathrm{L})$ was added to each well (final volume in the well: $200 \mu \mathrm{L}$ ). A growth control well (GCW) (containing medium, inoculum, and the same amount of DMSO used in a CTW, but compound-free) and a sterility control well (SCW) (sample, medium, and sterile water instead of inoculum) were included for each fungus tested. Microtiter trays were incubated in a moist, dark chamber at $30^{\circ} \mathrm{C}$ for $48 \mathrm{~h}$ for both yeasts. Microplates were read in a VERSA Max microplate reader (Molecular Devices, Sunnyvale, CA, USA). Amphotericin B (SigmaAldrich, St. Louis, USA) was used as positive control. Tests were performed in triplicate. Reduction of growth for each compound concentration was calculated as follows: inhibition $(\%)=100\left(\mathrm{OD}_{405} \mathrm{CTW}-\mathrm{OD}_{405} \mathrm{SCW}\right) /\left(\mathrm{OD}_{405}\right.$ $\mathrm{GCW}-\mathrm{OD}_{405} \mathrm{SCW}$ ), where $\mathrm{OD}_{405}$ is the optical density at $405 \mathrm{~nm}$. The concentration of each compound that produces $50 \%$ fungal growth reduction $\left(\mathrm{IC}_{50}\right)$ was taken as the MIC endpoint.

\section{In vitro antibacterial activity assays, phytopathogens}

Liquid-dilution methods were used to evaluate the effects of the compounds on the growth of E. carotovora (NCPPB 312), A. tumefaciens (strain C58C1) and P. syringae (NCPPB 281). Bacteria were grown in sterile tubes with $10 \mathrm{~mL}$ of Mueller-Hinton (MH) medium and incubated at $27{ }^{\circ} \mathrm{C}$ for $12 \mathrm{~h}$ with shaking, to produce an initial culture. The antimicrobial activity was evaluated by observing the growth response of both microorganisms in samples with different concentrations of the compounds. ${ }^{75-77}$ All assays were performed on sterile 96-well microplates with a final volume of $200 \mu \mathrm{L}$ containing $\mathrm{MH}$ broth inoculated with $1 \mu \mathrm{L}$ aliquots of bacterial suspension $\left(10^{5}-10^{6} \mathrm{CFU} \mathrm{mL}^{-1}\right.$, initial culture) in the presence of different concentrations of test compounds (3.9, 7.8, 15.6, $31.3,62.5,125$ and $250 \mu \mathrm{M})$. MH was used as the negative control (C-), and MH with streptomycin ${ }^{78}$ was used as the positive control $(\mathrm{C}+)$. The plates were incubated for $7 \mathrm{~h}$ at $27^{\circ} \mathrm{C}$. Bacterial growth was monitored by measuring the optical density at $595 \mathrm{~nm}$ every hour with a microplate reader. All tests were performed in ten repetitions for each microorganism evaluated. Bacterial growth was shown as the arithmetic mean expressed in terms of the negative control (100\% growth). The lowest concentration of the compound preventing the appearance of turbidity was considered to be the MIC.

The first experiment (first kinetic assay) in which the compound was exposed to the bacterial cultures in $\mathrm{MH}$ was carried out over a period of $6 \mathrm{~h}$. Subsequently, to determine the minimal bactericidal concentration (MBC), a second experiment (second kinetic assay) was conducted; this experiment involved taking inoculum from the first kinetic assay and adding it to $\mathrm{MH}$ in a new 96-well microplate, which was then cultured for $7 \mathrm{~h}$. The aim of this second culture (second kinetic assay) was to observe and quantify the ability of bacterial cultures to recover from the cytotoxic effect caused by the compounds, which is evidenced by the presence or absence of bacterial growth. This second experiment allows a more accurate conclusion to be reached: if the bacterial culture's growth declines with respect to the culture of the first kinetic assay, then it is related to a bactericidal property. If, on the other hand, the growth continues in line with that of the culture of first kinetic assay, then it is related to a bacteriostatic property.

\section{In vitro fungicidal activity assays, phytopathogens}

A virulent isolate of $B$. cinerea obtained from naturally infected grape berries ${ }^{79}$ was prepared and maintained by placing it on potato dextrose agar (PDA) at $5{ }^{\circ} \mathrm{C}$. P. cinnamomi was kindly provided by the National Institute of Agricultural Research (INIA, La Platina, Santiago, Chile). The fungus G. fujikuroi was kindly provided by Dr B. Fraga, Natural Products and Agrobiology Institute, CSIC, Canary Islands, Spain. The agar dilution technique was used to evaluate the effect of the chalcones on the growth of $P$. cinnamomi, ${ }^{80,81}$ G. fujikuroi ${ }^{82}$ and B. cinerea ${ }^{83,84}$ Fungicidal activity assays of these compounds were performed in microcultures by growing the fungi in sterile Petri dishes $(35 \mathrm{~mm})$ at a final volume of $2 \mathrm{~mL}$ medium containing different compound concentrations. Clarified V8 (Campbell Soup) medium containing metalaxy ${ }^{85}$ for P. cinnamomi or PDA medium for B. cinerea and G. fujikuroi with captan ${ }^{86,87}$ was used as the positive control $(\mathrm{C}+)$, and without fungicide as the negative control $(\mathrm{C}-)$. The medium in each slot was then inoculated with a small block $(4 \mathrm{~mm})$ of clarified V8 or PDA medium containing fungal hyphae excised from the edge of an actively growing culture. The fungal growth was monitored at different times (24-72 h). To determine the growth of mycelium in the agar plate, the surface of the mycelium was measured using Sigma Scan Pro 5 software. ${ }^{88}$ The final results are expressed as percent growth inhibition, calculated according to the control without fungicide. Each treatment was independently performed in triplicate.

\section{Statistics}

A one-way analysis of variance (ANOVA) was performed to identify significant differences among the 
treatment and control groups. Tukey's honest significant difference test was applied to compare the means of every treatment against the control and simultaneously establish their significance $(p<0.05)$. All data are presented as mean \pm standard deviation (S.D.).

\section{In vitro 5-LOX enzyme assay}

The commercially available enzyme 5 -hLOX by Cayman Chemicals Inc. (Ann Arbor, MI, USA) was diluted (1:500) in the assay buffer $50 \mathrm{mM}$ (4-(2-hydroxyethyl)1-piperazineethanesulfonic acid (HEPES), $2 \mathrm{mM}$ ethylenediamine tetraacetic acid (EDTA), $10 \mu \mathrm{M}$ adenosine triphosphate (ATP) and $10 \mu \mathrm{M} \mathrm{CaCl}_{2}$ at $\mathrm{pH}$ 7.5) and mixed with $10 \mu \mathrm{M}$ of $\mathrm{H}_{2}$ DCFDA dye the reaction mixture and incubated for $15 \mathrm{~min}$ in the assay plate. Later, $280 \mu \mathrm{L}$ of buffer and $10 \mu \mathrm{M}$ of inhibitor were added per well, and finally incubated for $30 \mathrm{~min}$ at $37{ }^{\circ} \mathrm{C}$. Finally, the reaction was started by adding a suitable concentration of arachidonic acid $(0.5 \mu \mathrm{M})$ and the fluorescence was read in a multimode detector Synergy ${ }^{\mathrm{TM}}$ HT Multi-Mode Microplate Reader (Biotek, Bad Friedrichshall, Germany) at $480 \mathrm{~nm}$ excitation $/ 520 \mathrm{~nm}$ emission after an incubation time of $1 \mathrm{~h}$ at room temperature. The $\mathrm{IC}_{50}$ values were obtained for analysis of oxidation of $\mathrm{H}_{2}$ DCFDA dye to the highly fluorescent 2',7'-dichloro-fluorescein (DCF) product and obtained by using the non-linear curve-fitting program. The kinetic assays to determine the mechanism of inhibition were done with the best inhibitors, using different concentrations of the inhibitor $(0-1 \mu \mathrm{M})$ and substrate $(0.2-5 \mu \mathrm{M})$. Experimental conditions were carried out as described previously. All data were collected in duplicate and the assays were performed on different days to ensure reproducibility of the method. The graphics for $\mathrm{IC}_{50}$ and kinetics studies were performed by GraphPad Prism Demo V.7. ${ }^{89}$

\section{Docking of chalcones with human 5-LOX}

The chalcone structures were built with the Molecular Operating Environment software..$^{90}$ ChelpG charges were obtained at the B3LYP/6-31G** level theory, employing the Gaussian 09 package. ${ }^{91}$ Docking of all inhibitors into the active site of the crystal structure of 5-hLOX (PDB code: 308 Y, $2.39 \AA$ A resolution) was performed with the AutoDock4 package, ${ }^{92}$ using a Lamarckian algorithm and assuming total flexibility of the inhibitors. The grid maps were made up to $60 \times 60 \times 60$ points, with a grid-point spacing of $0.375 \AA$ and the $\mathrm{Fe}^{3+}$ as the center of the grid map. The AutoTors option was used to define the ligand torsions, and the docking results were then analyzed by a ranked cluster analysis, resulting in conformations with the highest overall binding energy (most negative Gibbs free energy binding value, $-\Delta \mathrm{G}$ ).

General procedure to determine the DPPH radical scavenging activity

The radical scavenging activity of the chalcones towards the DPPH radical was measured as described, ${ }^{93}$ adapted to a screen of 96-well plates. Briefly, stock solutions of each compound were prepared in methanol at $1 \mathrm{mM}$ concentration $(10 \mathrm{~mL})$. Dilutions $(1-200 \mu \mathrm{M})$ were prepared from the stock solutions. Methanol $(90 \mu \mathrm{L})$, each dilution $(150 \mu \mathrm{L})$, and DPPH (60 $\mu$ L, Sigma-Aldrich, St. Louis, USA) in methanol $(0.5 \mathrm{mM})$, resulting in a final concentration of $0.1 \mathrm{mM}$ DPPH, were added in a 96-well plate. Methanol was used as the blank sample. The mixtures were left for $30 \mathrm{~min}$ at room temperature, and the absorbances were then measured at $517 \mathrm{~nm}$. Trolox was used as the standard antioxidant. The radical scavenging activity was calculated as follows: Inhibition $(\%)=[$ (blank absorbance - sample absorbance) / blank absorbance] $\times 100$. The mean of three $\mathrm{IC}_{50}$ (concentration causing 50\% inhibition) values for each compound was determined graphically.

\section{In vitro cytotoxic activity of $\mathbf{1 8}$}

The cell lines used in this work included MDA-MB-231 human breast adenocarcinoma cells, B16-F10 mouse metastatic melanoma cells and MEF primary mouse embryonic fibroblast. Cells were maintained in DMEM high glucose medium (Mediatech, Manassas, VA, USA) supplemented with 10\% (MDA-MB-231 and B16-F10) or $15 \%$ (MEF) heat-inactivated fetal bovine serum (HyClone Laboratories, South Logan, USA), $100 \mathrm{IU} \mathrm{mL}^{-1}$ penicillin and $100 \mu \mathrm{g} \mathrm{mL} \mathrm{m}^{-1}$ streptomycin and maintained at $37{ }^{\circ} \mathrm{C}$ in a $5 \% \mathrm{CO}_{2}$ humidified atmosphere. Cell viability was measured using CyQuant ${ }^{\circledR}$ Direct Cell Proliferation Assay Kit (Life Technologies, Grand Island, NY, USA) following the manufacturer's instruction. Briefly, 5000 cells well $^{-1}$ were seeded onto a flat-bottomed 96-well plate in $200 \mu \mathrm{L}$ final volume. Six hours after seeding, the culture medium was replaced with the medium containing the tested compounds at concentrations ranging from 0 up to $100 \mu \mathrm{M}$ dissolved in DMSO (0.1\% final concentration) during $72 \mathrm{~h}$. The concentrations used to calculate the $\mathrm{IC}_{50}$ values were: $100.0,30.0,10.0,3.0,1.0,0.3,0.1,0.01$ and $0.0 \mu \mathrm{M}$. Untreated cells (medium containing $0.1 \%$ DMSO) were used as controls. At the end of the incubation, $100 \mu \mathrm{L}$ of culture medium was removed from each experimental well and replaced by detection reagent solution provided by the 
kit (which is a 1:5 mix of the reagent CyQUANT ${ }^{\circledR}$ direct nucleic acid stain and the reagent labeled as CyQUANT ${ }^{\circledast}$ direct background suppressor I). Cells were incubated for $1 \mathrm{~h}$ and fluorescence emission was measured at $535 \mathrm{~nm}$ with excitation at $480 \mathrm{~nm}$ in a microplate reader (Infinite 200 PRO, Tecan, Grödig, Austria). At least four independent experiments were performed for each concentration. The results from each experiment were transformed to percentage of controls and the $\mathrm{IC}_{50}$ values were graphically obtained from the dose-response curves. The $\mathrm{IC}_{50}$ value was obtained adjusting the dose-response curve to sigmoidal curves (variable slope), generated using GraphPad Prisma 6.0 software. ${ }^{94}$

\section{Supplementary Information}

Supplementary information is available free of charge at http://jbcs.sbq.org.br as PDF file.

\section{Acknowledgments}

This work was supported by FONDECYT (grant No. 1130924), Dirección General de Investigación, Innovación y Postgrado (DGIIP) of the Universidad Técnica Federico Santa María, DICYT-USACH (grant No. 021601VM) and (grant No. 021641MC) of the Universidad de Santiago de Chile. S. Z. and M. R. thank the Agencia Nacional de Promoción Científica y Tecnológica (ANPCyT), grant PICT 2014-1170.

\section{References}

1. Aksöz, B. E.; Ertan, R.; FABAD J. Pharm. Sci. 2011, 36, 223.

2. Sebti, S.; Solhy, A.; Tahir, R.; Abdelatif, S.; Boulaajaj, S.; Mayoral, J. A.; García, J. I.; Fraile, J. M.; Kossir, A; Oumimoun, H.; J. Catal. 2003, 213, 1.

3. Kumar, S.; Lamba, M. S.; Makrandi, J. K.; Green Chem. Lett. Rev. 2008, 1, 123.

4. Ndoile, M. M.; van Heerden, F. R.; Beilstein J. Org. Chem. 2013, 9, 1346.

5. Sheng, R.; Lin, X.; Zhang, J.; Chol, K. S.; Huang, W.; Yang, B.; He Q.; Hu, Y.; Bioorg. Med. Chem. 2009, 17, 6692.

6. Syam, S.; Abdelwahab, S. I.; Al-Mamary, M. A.; Mohan, S.; Molecules 2012, 17, 6179.

7. Nagaraju, M.; Deepthi, E. G.; Ashwini, C.; Vishnuvardhan, M. V. P. S.; Nayak, V. L.; Chandra, R.; Ramakrishna, S.; Gawali, B. B.; Bioorg. Med. Chem. Lett. 2012, 22, 4314.

8. Daskiewicz, J. B.; Comte, G.; Barron, D.; Di Pietro, A.; Thomasson, F.; Tetrahedron Lett. 1999, 40, 7095.

9. Gall, E. L.; Texier-Boullet, F.; Hamelin, J.; Synth. Commun. 1999, 29, 3651.
10. Dong, X.; Zhang, Y.; He, J.-L.; Zhang, S.; Zeng, M.-M.; Chen, J.; Zheng, Z.-P.; Food Chem. 2016, 197, 589.

11. Nam, N.-H.; Kim, Y.; You, Y.-J.; Hong, D.-H.; Kim, H.-M.; Ahn, B.-Z.; Eur. J. Med. Chem. 2003, 38, 179.

12. Dong, F.; Jian, C.; Zhenghao, F.; Kai, G.; Zuliang, L.; Catal. Commun. 2008, 9, 1924.

13. Narender, T.; Reddy, K. P.; Tetrahedron Lett. 2007, 48, 3177.

14. Calloway, N. O.; Green, L. D.; J. Am. Chem. Soc. 1937, 59, 809.

15. Iranpoor, N.; Kazemi, F.; Tetrahedron 1998, 54, 9475.

16. Ren, Y.-M.; Zhang, Z.; Jin, S.; Synth. Commun. 2016, 46, 528.

17. Kakati, D.; Sarma, R. K.; Saikia, R.; Barua, N. C.; Sarma, J. C.; Steroids 2013, 78, 321.

18. Li, J.-T.; Yang, W.-Z.; Wang, S.-X.; Li, S.-H.; Li, T.-S.; Ultrason. Sonochem. 2002, 9, 237.

19. Rateb, N. M.; Zohdi, H. F.; Synth. Commun. 2009, 39, 2789.

20. Petrov, O.; Ivanova, Y.; Gerova, M.; Catal. Commun. 2008, 9 , 315.

21. Singh, P.; Anand, A.; Kumar, V.; Eur. J. Med. Chem. 2014, 85, 758.

22. Vandeputte, P.; Ferrari, S.; Coste, A. T.; Int. J. Microbiol. 2012, 2012, article ID 713687.

23. Mahapatra, D. K.; Bharti, S. K.; Asati, V.; Eur. J. Med. Chem. 2015, 101, 496.

24. Williamson, B.; Tudzynski, B.; Tudzynski, P.; Van Kan, J. A. L.; Mol. Plant Pathol. 2007, 8, 561.

25. Wulff, E. G.; Sørensen, J. L.; Lübeck, M.; Nielsen, K. F.; Thrane, U.; Jan Torp, J.; Environ. Microbiol. 2010, 12, 649.

26. Sepúlveda-Chavera, G.; Salvatierra-Martínez, R.; Bilbao-Apata, C.; Sepúlveda-Ramírez, P.; Allende-Castro, M.; AlacheGonzález, J.; Idesia 2013, 31, 41.

27. Gallo, L.; Siverio, F.; Rodríguez-Pérez, A.-M.; Ann. Appl. Biol. 2007, 150, 65 .

28. Jiménez, E.; Dorta, F.; Medina, C.; Ramírez, A.; Ramírez, I.; Peña-Cortés, H.; Mar. Drugs 2011, 9, 739.

29. El Khoury, W.; Makkouk, K.; J. Plant Pathol. 2010, 92, S4.35.

30. Yang, C.; Hamel, Ch.; Vujanovic, V.; Gan, Y.; ISRN Ecol. 2011, 2011, article ID 130289.

31. Díaz-Tielas, C.; Graña, E.; Reigosa, M. J.; Sánchez-Moreiras, A. M.; Planta Daninha 2016, 34, 607.

32. Guo, M.; Block, A.; Bryan, C. D.; Becker, D. F.; Alfano, J. R.; J. Bacteriol. 2012, 194, 5054.

33. Prajapat, R.; Marwal, A.; Jha, P. N.; Int. J. Curr. Microbiol. Appl. Sci. 2013, 2, 83.

34. Moore, L. W.; Pscheidt, J. W.; Pacific Northwest Plant Disease Management Handbook; Pscheidt, J. W.; Ocamb, C. M., eds.; Oregon State University: Corvallis, OR, USA, 2018. Available at https://pnwhandbooks.org/node/408/print, accessed in September 2018.

35. Lucera, A.; Costa, C.; Conte, A.; Del Nobile, M. A.; Front. Microbiol. 2012, 3, article 287. 
36. http://www.fao.org/fao-who-codexalimentarius/codex-texts/ maximum-residue-limits/en/, accessed on September 10, 2018.

37. Apak, R.; Özyürek, M.; Güçlü, K.; Çapanoğlu, E.; J. Agric. Food Chem. 2016, 64, 1046.

38. Chand, K.; Rajeshwari; Hiremathad, A.; Singh, M.; Santos, M. A.; Keri, R. S.; Pharmacol. Rep. 2017, 69, 281.

39. Karthikeyan, C.; Moorthy, N. S.; Ramasamy, S.; Vanam, U.; Manivannan, E.; Karunagaran, D.; Trivedi, P.; Recent Pat. AntiCancer Drug Discovery 2015, 10, 97.

40. Ghosh, J.; Myers, C. E.; Proc. Natl. Acad. Sci. U. S. A. 1998 , 95,13182 .

41. Steinhilber, D.; Fischer, A. S.; Metzner, J.; Steinbrink, S. D.; Roos, J.; Ruthardt, M.; Maier, T. J.; Front. Pharmacol. 2010, 1 , article 143 .

42. Chen, Y.; Zhang, H.; Zhou, H. J.; Ji, W.; Min, W.; Cancers 2016, 8 , article 40.

43. Reddy, N. P.; Aparoy, P.; Reddy, T. C. M.; Achari, C.; Bioorg. Med. Chem. 2010, 18, 5807.

44. Ball, A. K.; Beilstein, K.; Wittmann, S.; Sürün, D.; Saul, M. J.; Schnütgen, F.; Flamand, N.; Capelo, R.; Kahnt, A. S.; Frey, H.; Schaefer, L.; Marschalek, R.; Häfner, A.-K.; Steinhilber, D.; Biochim. Biophys. Acta 2017, 1862, 561.

45. Batovska, D.; Parushev, S.; Stamboliyska, B.; Tsvetkova, I.; Ninova, M.; Najdenski, H.; Eur. J. Med. Chem. 2009, 44, 2211.

46. Abreu, A. C.; McBain, A. J.; Simões, M.; Nat. Prod. Rep. 2012, 29, 1007

47. Butts, A.; Krysan, D. J.; PLoS Pathog. 2012, 8, e1002870.

48. Delattin, N.; De Brucker, K.; Vandamme, K.; Meert, E.; Marchand, A.; Chaltin, P.; Cammue, B. P. A.; Thevissen, K.; J. Antimicrob. Chemother. 2014, 69, 1035.

49. Tran, T. D.; Do, T. H.; Tran, N. C.; Ngo, T. D.; Huynh, T. N. P.; Tran, C. D.; Thai, K. M.; Bioorg. Med. Chem. Lett. 2012, 22 , 4555.

50. Pfaller, M. A.; Diekema, D. J.; Clin. Microbiol. Rev. 2007, 20 , 133.

51. Sato, M.; Tsuchiya, H.; Akagiri, M.; Fujiwara, S.; Fujii, T.; Takagi, N.; Matsuura, N.; Iinuma, M.; Lett. Appl. Microbiol. 1994, 18, 53.

52. Batovska, D.; Parushev, St. P.; Slavova, A.; Bankova, V.; Tsevetkova, I.; Ninova, M.; Najdenski, H.; Eur. J. Med. Chem. 2007, 42, 87.

53. Lathtchev, K. L.; Batovska, D.; Parushev, St. P.; Ubiyvovk, V. M.; Sibirny, A. A.; Eur. J. Med. Chem. 2008, 43, 2220.

54. Gupta, D.; Jain, D.; J. Adv. Pharm. Technol. Res. 2015, 6, 114.

55. Mishra, P.; Sarma, B.; Singhai, P.; Singh, U.; Mycobiology 2007, 35,72 .

56. Jayasinghe, L.; Balasooriya, B. A.; Padmini, W. C.; Hara, N.; Fujimoto, Y.; Phytochemistry 2004, 65, 1287.

57. Nowakowska, Z.; Eur. J. Med. Chem. 2007, 42, 125.

58. López, S. N.; Castelli, M. V.; Zacchino, S. A.; Domínguez, J. N.;
Lobo, G.; Charris-Charris, J.; Cortés, J. C.; Ribas, J. C.; Devia, C.; Rodríguez, A. M.; Enriz, R. D.; Bioorg. Med. Chem. 2001, 9, 1999.

59. Clinical and Laboratory Standards Institute (CLSI); CLSI Document M27-A3: Reference Method for Broth Dilution Antifungal Susceptibility Testing of Yeasts; Approved Standard, $3^{\text {rd }}$ ed.; CLSI: Wayne, PA, 2008.

60. Swinne, D.; Watelle, M.; Nolard, N.; Rev. Iberoam. Micol. 2005, $22,24$.

61. Mascayano, C.; Espinosa, V.; Sepúlveda-Boza, S.; Hoobler, E. K.; Perry, S.; Chem. Biol. Drug Des. 2013, 82, 317.

62. Mascayano, C.; Espinosa, V.; Sepúlveda-Boza, S.; Hoobler, E. K.; Perry, S.; Diaz, G.; Holman, T. R.; Chem. Biol. Drug Des. 2015, 86, 114.

63. Aldrich, C.; Bertozzi, C.; Georg, G. I.; Kiessling, L.; Lindsley, C.; Liotta, D.; Merz Jr., K. M.; Schepartz, A.; Wang, S.; ACS Cent. Sci. 2017, 3, 143.

64. Haruta, S.; Kanno, N.; Microbes Environ. 2015, 30, 123.

65. Rao, Y. K.; Fang, S.-H.; Tzeng, Y.-M.; Bioorg. Med. Chem. 2009, 17, 7909.

66. Goswami, P.; Talukdar, M.; Bora, T. C.; Phukan, P.; Sarma, J. C.; C. R. Chim. 2013, 16, 442.

67. Kumar, V.; Kumar, S.; Hassan, M.; Wu, H.; Thimmulappa, R. K.; Kumar, A.; Sharma, S. K.; Parmar, V. S.; Biswal, S.; Malhotra, S. V.; J. Med. Chem. 2011, 54, 4147.

68. Pathak, V.; Ahmad, I.; Kahlon, A. K.; Hasanain, M.; Sharma, S.; Srivastava, K. K.; Sarkar, J.; Shankar, K.; Sharma, A.; Gupta, A.; RSC Adv. 2014, 4, 35171.

69. Mohamed, N.; Hamada, M.; Yousef, N.; Abdo, M.; Molecules 2015, 20, 10468.

70. Kakati, D.; Sarma, J. C.; Chem. Cent. J. 2011, 5, article 8.

71. Zhang, J.; Fu, X.-L.; Yang, N.; Wang, Q.-A.; Sci. World J. 2013, article ID 649485

72. Clinical and Laboratory Standards Institute (CLSI); CLSI Document M26-A: Methods for Determining Bactericidal Activity of Antimicrobial Agents; Approved Guideline; CLSI: Wayne, PA, USA, 1999.

73. Iten, F.; Saller, R.; Abel, G.; Reichling, J.; Planta Med. 2009, $75,1231$.

74. Doern, C. D.; J. Clin. Microbiol. 2014, 52, 4124.

75. Cole, M. D.; Biochem. Syst. Ecol. 1994, 22, 837.

76. Zampini, I. C.; Vattuone, M. A.; Isla, M. I.; J. Ethnopharmacol. $\mathbf{2 0 0 5}, 102,450$.

77. Cos, P.; Vlietinck, A. J.; Berghe, D. V.; Maes, L.; J. Ethnopharmacol. 2006, 106, 290.

78. McManus, P. S.; Stockwell, V. O.; Sundin, G. W.; Jones, A. L.; Ann. Rev. Phytopathol. 2002, 40, 443.

79. Riggoti, S.; Gindro, K.; Richter, H.; Viret, O.; FEMS Microbiol. Lett. 2002, 209, 169.

80. Bekker, T.; Labuschagne, N.; Kaiser, C.; S. Afr. Avocado Grow. Assoc. Yearb. 2005, 28, 60. 
81. Horta, M.; Sousa, N.; Coelho, A. C.; Neves, D.; Cravador, A.; Physiol. Mol. Plant Pathol. 2008, 73, 48.

82. Azor, M.; Gené, J.; Cano, J.; Sutton, D. A.; Fothergill, A. W.; Rinaldi, M. G.; Guarro, J.; Antimicrob. Agents Chemother. 2008, $52,2228$.

83. Salzman, R. A.; Tikhonova, I.; Bordelon, B. P.; Hasegawa, P. M.; Bressan, R. A.; Plant Physiol. 1998, 117, 465.

84. Kirubakaran, S. I.; Begum, S. M.; Ulaganathan, K.; Sakthivel, N.; Plant Physiol. Biochem. 2008, 46, 918.

85. Zhu, G.; Huang, F.; Feng, L.; Qin, B.; Yang, Y.; Hen, Y.; Lu, X.; Agric. Sci. China 2008, 7, 831.

86. Meepagala, K. M.; Sturtz, G.; Wedge, D. E.; J. Agric. Food Chem. 2002, 50, 6989.

87. Alizadeh, H. R.; Sharifi-Tehrani, A.; Hedjaroude, G. A.; Commun. Agric. Appl. Biol. Sci. 2007, 72, 795.

88. Sigma Scan Pro V. 5.0; Systat Software Inc., Chicago, Illinois, USA, 2008.

89. GraphPad Prism Demo V.7.; GraphPad Software Inc., La Jolla California, USA, 2017.

90. Molecular Operating Environment (MOE), 2013.08; Chemical Computing Group ULC, Montreal, QC, Canada, 2018.

91. Frisch, M. J.; Trucks, G. W.; Schlegel, H. B.; Scuseria, G. E.; Robb, M. A.; Cheeseman, J. R.; Scalmani, G.; Barone, V.; Petersson, G. A.; Nakatsuji, H.; Li, X.; Caricato, M.; Marenich, A.; Bloino, J.; Janesko, B. G.; Gomperts, R.; Mennucci, B.;
Hratchian, H. P.; Ortiz, J. V.; Izmaylov, A. F.; Sonnenberg, J. L.; Williams-Young, D.; Ding, F.; Lipparini, F.; Egidi, F.; Goings, J.; Peng, B.; Petrone, A.; Henderson, T.; Ranasinghe, D.; Zakrzewski, V. G.; Gao, J.; Rega, N.; Zheng, G.; Liang, W.; Hada, M.; Ehara, M.; Toyota, K.; Fukuda, R.; Hasegawa, J.; Ishida, M.; Nakajima, T.; Honda, Y.; Kitao, O.; Nakai, H.; Vreven, T.; Throssell, K.; Montgomery Jr., J. A.; Peralta, J. E.; Ogliaro, F.; Bearpark, M.; Heyd, J. J.; Brothers, E.; Kudin, K. N.; Staroverov, V. N.; Keith, T.; Kobayashi, R.; Normand, J.; Raghavachari, K.; Rendell, A.; Burant, J. C.; Iyengar, S. S.; Tomasi, J.; Cossi, M.; Millam, J. M.; Klene, M.; Adamo, C.; Cammi, R.J.; Ochterski, W.; Martin, R. L.; Morokuma, K.; Farkas, O.; Foresman, J. B.; Fox, D. J.; Gaussian 09, Revision A.02; Gaussian, Inc., Wallingford, CT, 2016.

92. Morris, G. M.; Huey, R.; Lindstrom, W.; Sanner, M. F.; Belew, R. K.; Goodsell, D. S.; Olson, A. J.; J. Comput. Chem. 2009, $16,2785$.

93. Osorio, M.; Quiroz, K.; Carvajal, M.; Vergara, A.; Sánchez, E.; González, C.; Catalán, K.; J. Chil. Chem. Soc. 2016, 61, 3095.

94. GraphPad Prism, version 6.00 for Mac OS X; GraphPad Software, La Jolla, California, USA, 2015.

Submitted: July 9, 2018

Published online: September 13, 2018 